\title{
Pseudomonas aeruginosa Biofilm Formation and Its Control
}

\author{
Aishwarya Vetrivel ${ }^{1}$ (D), Monica Ramasamy ${ }^{1}$, Preethi Vetrivel ${ }^{2}$, Santhi Natchimuthu ${ }^{1} \mathbb{D}$, Shobana Arunachalam ${ }^{1}$, \\ Gon-Sup Kim ${ }^{2}$ (D) and Rajeswari Murugesan ${ }^{1, *}$
}

1 Department of Biochemistry, Biotechnology and Bioinformatics, Avinashilingam Institute for Home Science and Higher Education for Women, Coimbatore 641043, India; aishuvetrivel@gmail.com (A.V.); monicamoni653@gmail.com (M.R.); santhi_bc@avinuty.ac.in (S.N.); shoba.s1823@gmail.com (S.A.)

2 Research Institute of Life Science, College of Veterinary Medicine, Gyeongsang National University, Gajwa-dong, Jinju 52828, Korea; preethivetrivel05@gmail.com (P.V.); gonskim@gnu.ac.kr (G.-S.K.)

* Correspondence: rajeshwari_bc@avinuty.ac.in; Tel.: +91-95-9741-9890

Citation: Vetrivel, A.; Ramasamy, M.; Vetrivel, P.; Natchimuthu, S.;

Arunachalam, S.; Kim, G.-S.;

Murugesan, R. Pseudomonas aeruginosa Biofilm Formation and Its Control. Biologics 2021, 1, 312-336. https://doi.org/10.3390/

biologics1030019

Academic Editor: Leodevico L. Ilag

Received: 18 August 2021

Accepted: 11 October 2021

Published: 15 October 2021

Publisher's Note: MDPI stays neutral with regard to jurisdictional claims in published maps and institutional affiliations.

Copyright: (c) 2021 by the authors. Licensee MDPI, Basel, Switzerland. This article is an open access article distributed under the terms and conditions of the Creative Commons Attribution (CC BY) license (https:// creativecommons.org/licenses/by/ $4.0 /)$.

\begin{abstract}
Microbes are hardly seen as planktonic species and are most commonly found as biofilm communities in cases of chronic infections. Biofilms are regarded as a biological condition, where a large group of microorganisms gets adhered to a biotic or abiotic surface. In this context, Pseudomonas aeruginosa, a Gram-negative nosocomial pathogen is the main causative organism responsible for life-threatening and persistent infections in individuals affected with cystic fibrosis and other lung ailments. The bacteria can form a strong biofilm structure when it adheres to a surface suitable for the development of a biofilm matrix. These bacterial biofilms pose higher natural resistance to conventional antibiotic therapy due to their multiple tolerance mechanisms. This prevailing condition has led to an increasing rate of treatment failures associated with P. aeruginosa biofilm infections. A better understanding of the effect of a diverse group of antibiotics on established biofilms would be necessary to avoid inappropriate treatment strategies. Hence, the search for other alternative strategies as effective biofilm treatment options has become a growing area of research. The current review aims to give an overview of the mechanisms governing biofilm formation and the different strategies employed so far in the control of biofilm infections caused by P. aeruginosa. Moreover, this review can also help researchers to search for new antibiofilm agents to tackle the effect of biofilm infections that are currently imprudent to conventional antibiotics.
\end{abstract}

Keywords: Pseudomonas aeruginosa; biofilm; quorum sensing; antibiotics; resistance; medicinal plants; enzymes; in silico screening

\section{Introduction}

Naturally, microorganisms exist either as free-floating cells or enclosed within an architectural structure known as biofilms [1]. One of the preferred growth states for bacteria is a biofilm, which exists in more than $90 \%$ of bacteria [2]. In such an environmental niche, the bacterial communities are regulated by various biological processes and use advanced genotypic events to promote different molecular mechanisms and phenotypes that are necessary for survival in the new environment during pathogenesis and antibiotic treatment [3]. Thus, a biofilm is regarded as a group of microorganisms encased within a self-secreted polymeric extracellular substances matrix attached to a surface irreversibly and difficult to be detached by a tender rinse [4,5]. Biofilms form on a huge range of surfaces that includes living tissues, hotels, industrial places, labs, wastewater channels, bathrooms, indwelling medical devices, and are frequently found on hard surfaces immersed in or exposed to an aqueous solution [6]. Nearly $99.9 \%$ of all microbes can develop biofilms on both biotic and abiotic surfaces [7].

Biofilms are heterogenous with $15 \%$ of cells, usually in microcolonies, and $85 \%$ of polymeric extracellular substances. The composition of the biofilm matrix varies among different species, but in general contains proteins, polysaccharides, and nucleic acids [8]. 
Structural support and protection for bacteria in biofilms are rendered by the extracellular matrix [9]. The matrix is also involved in various other processes such as adherence to surfaces, cell-to-cell communication, quorum sensing (QS), tolerance, etc. [1].

Biofilm matrix development and bacterial growth are dependent on factors, namely, availability of nutrients and hydrodynamic conditions [10]. The cooperative interactions among species lead to various development states, structures, and functions of biofilm organization [11]. Biofilms are considered polymicrobial and hence there is a huge rivalry for nutrients and space. The cohabitation of numerous microbes on a surface promotes cooperative behaviors such as metabolic cooperation, horizontal gene transfer, and other synergies, thereby leading to an increased potential of microorganisms to survive and exhibit resistance to antimicrobial agents $[12,13]$.

The presence of biofilms on man-made surfaces imparts its significance in connection to pathogenicity, whereas biofilm formation in undesirable places may lead to medical and industrial complications as they show resistance to cellular immunity in the host, antimicrobial, and biocide treatments [1]. This concept of biofilm was first discovered by Anton Van Leeuwenhoek in 1684 when he was observing the surface of a tooth using a primitive microscope [14]. A biofilm could not be removed with ease adopting a standard clinical procedure and could be detached only by complete elimination of the infected implant, which increases the trauma rate of the patients and treatment cost [15].

Resistance to antibiotics is approximately 1000 fold more in attached bacteria than planktonic cells because of an increase in mutation rates, upregulation of efflux pumps, decrease in metabolic activity, and other physical reasons [16]. The resistance mechanism is unique to biofilm-encapsulated bacteria as the biofilm phenotype provides a protective advantage [17].

Biofilms hold a significant role in healthcare-associated infections (HAI), in particular those connected to the implant of medical devices, namely urinary catheters, orthopedic implants, and intravascular catheters. Annually, as reported by the European Center for Disease Prevention and Control (2008), around 4,100,000 patients acquire HAI in European hospitals, and the number of deaths due to these infections are estimated to be around 37,000 [18]. Approximately, there are 200,000 cases of bloodstream infections in the United States every year due to implants of central venous catheters [19].

According to recent reports, it is estimated that 449,334 patients are affected per year in US hospitals due to catheter-associated urinary tract infections (UTIs) [20]. Among various biofilm-associated infections, UTIs are the most common bacterial infections affecting humans and serve as a public health issue [21]. Nevertheless, in 2017, bloodstream infections associated with biofilms were ranked as the 12th leading cause for death with an overall mortality rate between $15-30 \%$ [22].

At present, approximately $80 \%$ of all microbial infections are of biofilm origin, out of which, $60-70 \%$ are nosocomial infections caused by biofilms on implanted medical devices [23]. In a clinical environment, nosocomial infections account for merely $65 \%$ of hospital-acquired infections [24,25]. Even after more than 70 years since the first report on biofilms [26], still there is a need in various areas such as biomedical and environmental fields related to the problems encountered by biofilms [27,28].

In such a case, the most studied organism related to QS and biofilms is the Gramnegative bacterium $P$. aeruginosa as it is one of the most virulent opportunistic pathogens, which leads to a variety of acute infections and continues to possess a high rate of mortality and antibiotic failure [29]. According to literature reviewed recently, P. aeruginosa was found to be the fourth most frequently found pathogen, contributing to around eight percent of chronic wound infections, and the seventh leading pathogen, contributing to around two to six percent of bloodstream infections. Further, epidemiological studies have proved that infections of $P$. aeruginosa could significantly increase the rate of mortality, morbidity, need for surgical intervention, chronic care, and overall cost of treatment [30]. Hence, focusing on the potent treatment strategies to prevent $P$. aeruginosa associated biofilm infections is the present area of concern. 


\section{Formation of Biofilm}

Biofilms may be defined as "Microbial communities consisting of various bacterial cells living in close association by encasing itself in an extracellular matrix made up of polymeric substances (EPS), adhered to a substratum or each other and exhibit an altered phenotype" $[14,31]$. The growth of bacteria within biofilms is a naturally occurring phenomenon in which the whole of the microbe could be lively attached to an infection site. The ability of the bacteria to colonize the environment and to mature as a biofilm on a surface is considered as one of the survival strategies for biofilm-forming microorganisms [32].

In general, microorganisms are found as organized groups that grow on diverse surfaces to constitute a distinct growth phase compared to free-swimming planktonic cells [33]. Formation of biofilm is a complex and cyclic phenomenon that involves transportation, diffusion, chemical reaction, ecological mechanisms, and is controlled by mechanisms that include bulk transport, adhesion, quorum sensing, detachment, death of cells, and dispersal [34,35]. Thus, biofilms are regarded as structural architectural organizations of microorganisms that evolve constantly to get adapted to their surroundings [36].

Bacterial biofilms could be well established in a few hours [37]. The formation of biofilm comprises of four main stages: (a) Initial attachment of planktonic bacteria to a surface through physical forces and interaction occurs between bacteria and surface of attachment; (b) Adherent cells gets attached to the surface irreversibly and encase themselves in extracellular polymeric substances matrix resulting in aggregation of cells; (c) Maturation of biofilm by microcolony formation to form a three-dimensional architecture of completely matured biofilm; (d) Release of microcolonies of cells from the matured biofilm to colonize new attachment site for spreading its infection [38].

Synthesis of extracellular matrix holds a crucial role in the biofilm development as it incorporates all the elements that make up $90 \%$ of the total organic matter o found in the matrix material, the most important structural feature of bacterial biofilms [39]. The components of the matrix include nucleic acids, lipids, polysaccharides, and proteins [40].

The functions of the matrix elements are to deceive nutrients, give structural support, and provide protection against natural resistance and antibiotic therapies in the host [41]. EPS holds all the cells of biofilm in the near vicinity to enable intercellular interactions (QS) and facilitate the genetic material exchange by gene transfer method [42]. It is reported that extracellular DNA (eDNA) is necessary for pathogens to adhere and for its cell-to-cell coherence at the early stage of biofilm development [43].

The characteristic features of a matured biofilm in general are, [34]

1. Adherence to each other

2. Adherence to either solid/liquid, solid/air, liquid/liquid, or liquid/air interfaces

3. Attachment to surfaces

4. Decreased antimicrobial susceptibility

5. Decreased host defense systems

6. Existence of one or more microbial species

7. Three-dimensional structure

At present, biofilms are well known to possess a biological role and pose a significant issue in medicine as they are responsible for a lot of healthcare-related diseases. According to the National Institute of Health (NIH), it is identified that biofilms formed by bacteria account for around $65 \%$ of infectious diseases caused by microbes and chronic infections by about $80 \%$ [38]. The most common biofilm-associated infections caused in humans are chronic sinusitis, wound infection, osteomyelitis, prosthetic joint infection, prosthetic valve endocarditis, infections of cystic fibrosis patients, ventilator-related pneumonia, intravascular catheter infection, and breast implant infections [44].

Biofilms cause infections by colonizing on inert surfaces, on dead tissues, on living tissues, and more commonly by dwelling on implanted devices like contact lenses, orthopedic implants, urinary catheters, peritoneal dialysis catheters, central venous catheters, prosthetic joints, pacemakers, mechanical heart valves, voice prostheses, implantable electronic devices, and other orthopedic and dental implants made up of composites and 
ceramics $[15,38,45]$. Some of the other non-device-related infections are chronic infections, periodontitis, and osteomyelitis [46]. Microbial adhesion in implanted medical devices may be made of single or multiple types of microbial species depending on the device and its duration of action but are more severe and can cause life-threatening complications [38].

The matured biofilms could be detected by several biofilm detection methods that can be categorized into four divisions: physical, chemical, microscopical, and biological techniques [47]. Some of the notable techniques include congo red agar, tube culture, microtiter plate assay, and in particular, the biofilm architecture could be studied elaborately by examining it using confocal laser scanning microscopy, optical sectioning, three-dimensional imaging, and scanning electron microscopy [31,34]. These biofilm techniques also possess certain properties such as in situ monitoring, real-time monitoring, and online monitoring, which can categorize and qualify the biofilms formed, and are representative, reproducible, accurate, and automatic [47]. The results obtained from these techniques are the 2D distribution of bacteria in the biofilm, total cell counts, the 3D structure of biofilm, microbial activity, and identification of different components of biofilms [48].

A typical type of potent biofilm causing infectious microorganisms are Pseudomonas aeruginosa, Burkholderia cepacia, Pseudomonas pseudomallei, Haemophilus influenza, Escherichia coli, Candida albicans, Streptococcus pyogenes, Streptococcus pneumonia, other Streptococcus species, Staphylococcus epidermidis, and Staphylococcus aureus [15,45,49]. Among these, S. aureus and S. epidermidis contribute to about $87 \%$ of bloodstream infections, $50-70 \%$ of catheter infections and, $40-50 \%$ of prosthetic heart valve infections [50]. Though S. aureus and coagulase-negative staphylococci are associated with the majority of implantable device-related infections, $P$. aeruginosa can readily adapt itself to harsh environments and antibiotics instantly, thus making it a suitable in vitro model for studying biofilm formation [51].

\section{Pseudomonas aeruginosa Biofilms}

P. aeruginosa is a virulent rod-shaped, Gram-negative bacterium belonging to the group of Pseudomonadaceae and found extensively inhabiting the water, plants, soil, and animals, which hardly cause infections in healthy individuals, but can easily cause infections in immune-compromised individuals [52]. For more than a decade, $P$. aeruginosa is among the 'top 10 ' common hospital 'superbugs' because of its widespread antimicrobial-resistant strains that cause life-threatening complications [53]. It is the most commonly isolated species from chronic wounds and is considered a potent biofilm producer since they act as a barrier in wound healing and exhibits high resistance to antimicrobial therapy [54,55].

According to US National Healthcare Safety (2007), P. aeruginosa was ranked to be the sixth most commonly occurring organism responsible for nosocomial infections, second most common pathogen responsible for ventilator related pneumonia, and seventh major causative pathogen of catheter-linked bloodstream infections accounting for high death rate in individuals with AIDS, cystic fibrosis, and burn wounds [56-58].

$P$. aeruginosa causes infections with the aid of several cell-based virulence factors such as pili, lectins, alginate, lipopolysaccharide, and secreted virulence factors, namely, pyocyanin, cytotoxin, proteases, hemolysins, siderophores, exotoxin A, exoenzyme $\mathrm{U}$, exoenzyme $S$, etc. respectively [59].

The mechanism intricated in the development of biofilm by P. aeruginosa is initially a free-floating bacterium gets reversibly adhered to a conditioned surface, then the adherent bacteria are irreversibly attached by surface adhesins followed by the formation of an extracellular matrix to produce a completely matured biofilm. Finally, dispersion of bacteria occurs from the matrix to colonize other surfaces (Figure 1). 


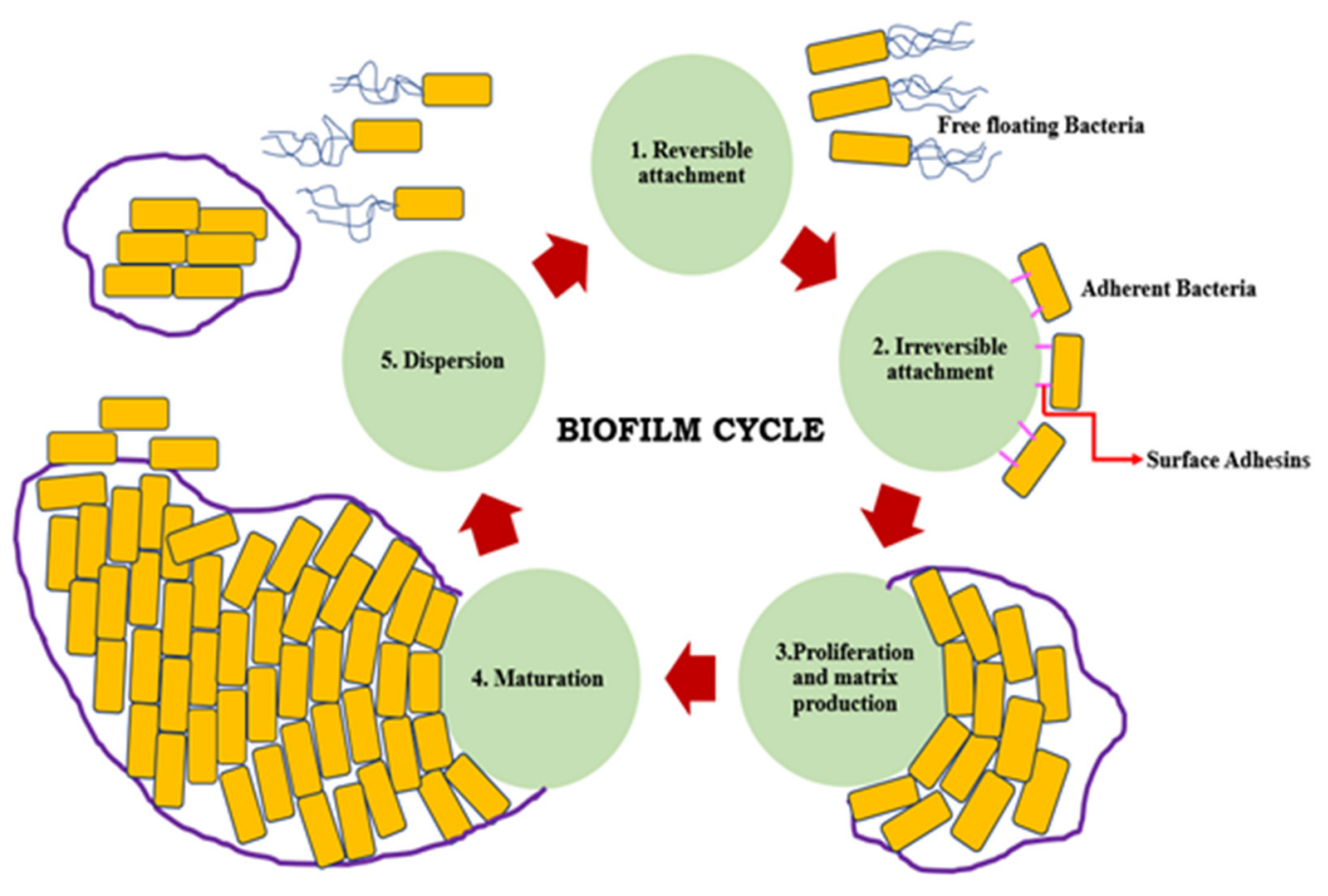

Figure 1. Cyclic process of biofilm formation in P. aeruginosa.

The stability of $P$. aeruginosa biofilm structure is determined by various polysaccharides, which include alginate, pel, and psl $[60,61]$. Alginate is an unbranched polymer chain consisting of D-mannuronic acid and L-glucuronic acid. This polymer is essential for the protection and stability of the biofilm structure. Alginate also contributes to the preservation of contents of the matrix such as nutrients and water [62]. Pel polysaccharide is a matrix material enriched with glucose, but with its composition still unknown and psl is a pentasaccharide composed of repeating residues of D-mannose, L-rhamnose, and D-glucose. Both these polysaccharides are implicated in the initial biofilm development stages by serving as a primary structure scaffold [63-65]. Another crucial element of $P$. aeruginosa biofilm is eDNA, which is regarded as a nutrient source for embedded bacteria and plays a key role in cell-to-cell interconnection $[8,66]$.

Synthesis of alginate, pel, and psl polysaccharides is regulated by bis-(3-5)-cyclic dimeric guanosine monophosphate (c-di-GMP), an intercellular ubiquitous second messenger that is widespread in bacteria [67]. Higher concentrations of c-di-GMP promote alginate and pel polysaccharides production and lower concentrations of c-di-GMP enhance the motility of bacteria, but the exact mechanism that regulates the polymerization of these polysaccharides precursors are still unknown [68].

Each polysaccharide is encoded on unique sites of the genome in which alginate is coded by a 12 gene operon, pel by a 7 gene operon, and psl by a 12 gene operon. The functions of different genes encoded by alginate, pel, and psl polysaccharides are presented in Table $1[65,69,70]$. 
Table 1. Functions of alginate, pel, and psl polysaccharide encoded genes.

\begin{tabular}{|c|c|c|c|}
\hline Polysaccharide & Gene & Function & References \\
\hline \multirow{12}{*}{ Alginate } & $A \lg D$ & Sugar nucleotide production & [71] \\
\hline & $A \lg 8$ & Subunit polymerization & [72] \\
\hline & $\operatorname{Alg} 44$ & c-di-GMP binding & [73] \\
\hline & $A \lg K$ & Outer membrane protein/secretion & {$[74]$} \\
\hline & $A \lg E$ & Outer membrane protein/secretion & [74] \\
\hline & $A \lg G$ & Epimerase/modification & [75] \\
\hline & $A \lg X$ & Epimerase/modification & [76] \\
\hline & $A \lg L$ & Hydrolase/lyase & {$[77]$} \\
\hline & $A \lg I$ & O-Acetylation & [78] \\
\hline & $A \lg J$ & O-Acetylation & [76] \\
\hline & $A \lg F$ & O-Acetylation & [78] \\
\hline & $A \lg A$ & Sugar nucleotide production & [79] \\
\hline \multirow{7}{*}{ Pel } & PelA & Hydrolase/lyase & {$[80]$} \\
\hline & PelB & Outer membrane protein/secretion & [81] \\
\hline & PelC & Outer membrane protein/secretion & [82] \\
\hline & PelD & c-di-GMP binding & [83] \\
\hline & PelE & Subunit polymerization & [84] \\
\hline & PelF & Glycosyl transferase & [85] \\
\hline & PelG & Inner membrane protein & [86] \\
\hline \multirow{12}{*}{ Psl } & PslA & Subunit polymerization & [87] \\
\hline & PslB & Sugar nucleotide production & {$[79]$} \\
\hline & PslC & Glycosyl transferase & [72] \\
\hline & PslD & Outer membrane protein/secretion & [88] \\
\hline & PslE & Wzz/Wzc like protein & [89] \\
\hline & PslF & Glycosyl transferase & [90] \\
\hline & PslG & Hydrolase/lyase & [91] \\
\hline & PslH & Glycosyl transferase & {$[90]$} \\
\hline & PslI & Glycosyl transferase & [90] \\
\hline & PslJ & Inner membrane protein & [86] \\
\hline & PslK & Inner membrane protein & [86] \\
\hline & PslL & Inner membrane protein & [86] \\
\hline
\end{tabular}

\section{Role of Quorum Sensing (QS) in Biofilm Formation}

An intercellular signaling system known as QS imparts a major part in the formation of biofilms by regulating gene expression using small molecules called autoinducers [92]. The development and structural integrity of the biofilm is merely dependent upon QS [93]. QS is a cell-to-cell interconnection mechanism that prevents cell density from reaching a threshold level to control its population density [94].

A level at which the autoinducers reach a threshold concentration at a specific cell density is referred to as "quorum level". At this level, autoinducers bind to their respective receptors to increase or decrease the activity of several genes responsible for maintaining the size of biofilm and coordinating phenotypic virulence [40,95]. Thus, the viability of the biofilm community is always dependent upon quorum sensing or quorum diffusions [93]. 
Generally, QS networks in Gram-negative bacteria and Gram-positive bacteria are modulated by signaling molecules such as $\mathrm{N}$-acyl homoserine lactones and oligopeptides, respectively. Another signaling molecule, namely, autoinducer-2 (AI-2) regulates QS in both types of bacteria [96]. Gram-negative bacteria, P. aeruginosa access Acyl Homoserine Lactones (AHLs) as its signaling molecule for regulating its QS networks. AHL molecules consist of a fatty acyl chain connected by an amide bond to lactonized homoserine. Different AHL molecules are synthesized by various bacterial species or the same bacterial species may synthesize different AHLs. Variations in composition of acyl chains contribute to various physiological and biochemical functions of the bacterial species [97].

A wide range of regulatory proteins involved in the QS mechanism of Gram-negative bacteria have been identified, among them, LuxR-type protein is the widely studied model since most of the members of this protein are AHL-responsive transcriptional activators [98]. LuxR-type proteins have two domains, namely, an N-terminus acyl-HSL-binding site and a C-terminus DNA binding site. The binding of acyl-HSL to the N-terminus domain promotes configurational changes that enable multimerization and DNA binding for transcriptional activation of the associated promoters $[99,100]$.

The advantage of QS lies not only in controlling population density, but also in spreading beneficial mutations to colonies of biofilms, which induce accessibility to nutrients and tolerance to antibiotics [101]. Inadequacy in the regulation of QS networks alters the structure and architecture of biofilms [62].

As QS pose a trivial impact on most of the regulatory processes, interrupting this mechanism serves as a critical approach and target of interest to control biofilm-forming pathogens [102,103]. Many approaches have been so far reported to hinder QS such as blocking of signal receptors and signal transduction, enzymatic degradation of signaling molecules, preventing autoinducers synthesis, etc., which destroyed biofilms completely by the host immune system $[104,105]$.

\section{Pseudomonas aeruginosa Quorum Sensing System}

Among the various QS systems studied in different species, the P. aeruginosa QS system is considered an important one because of its severe pathogenicity. P. aeruginosa QS system is controlled by various pathways and exhibits interrelated effects [106]. The importance of the QS system in P. aeruginosa biofilms was first reported in 1998 by Davis and his group [107]. Four types of QS systems have been so far studied in P. aeruginosa. They are las, rhl, pqs, and integrated QS (IQS). IQS was added to the P. aeruginosa QS system recently and hence its mechanism is not much exploited [108]. The las system is made up of LasI synthase that induce the synthesis of signaling molecule $\mathrm{N}$-(3-oxododecanoyl)L-homoserine lactones (3-oxo-C12-HSL), recognized by its LuxR-type receptor protein LasR to activate transcription of target genes. In the $r h l$ system, the signaling molecule N-butanoyl-L-homoserine lactone (C4-HSL) synthesized by RhlI synthase is recognized by its signal receptor RhlR to induce regulation of target gene expression [109]. Among these two LuxR-type receptor proteins, LasR is activated the earliest and regulates the expression of RhlR [110]. Both las and rhl systems are not only involved in biofilm formation but also regulate various gene expressions necessary for virulence factors production [108].

LasR protein is made up of two independently folded domains, an N-terminus ligand binding region, and a C-terminus DNA binding region [111]. By comparing the wildtype strain of biofilm with that of mutant lasI biofilm strains, Davies et al. [107] reported the importance of the las system in the development and maturation of biofilms. The mechanism of LasR is, LasR stabilizes itself and undergoes dimerization on binding to a signaling molecule and the resulting LasR homodimer complex regulates the transcriptional activation of target genes [112]. It was reported by Gilbert et al. [113] that LasR binds to the psl operon in the promoter region and regulates psl expression.

On the other hand, RhIR binds to C4-HSL or an alternative signaling molecule synthesized by PqsE, a thioesterase intricated in alkyl quinolone synthesis to activate genes necessary for the production of virulence-associated QS factors and formation of biofilms [114]. 
C4-HSL does not stabilize RhlR [115] like the way LasR is stabilized since RhlR does not bind C4-HSL tightly, as evidenced by Boursier et al. [116]. The rhl system of P. aeruginosa is involved in biofilm formation by modulating the synthesis of Pel polysaccharides [62].

The third QS system $p q s$ synthesizes signaling molecule 2-heptyl-3-hydroxy-4-quinolone (PQS) that recognizes its cognate receptor PqsR for regulating eDNA release during biofilm formation $[117,118]$. Apart from this, the $p q s$ system also regulates other metabolic processes in P. aeruginosa such as the secretion of elastase, rhamnolipid, the formation of membrane, and so on $[119,120]$. Many researchers suggested pqs as important for virulence and it is increasingly seen in patients with cystic fibrosis affected by P. aeruginosa infections [121-124].

Recently discovered QS system IQS produces autoinducer molecule 2-(2-hydroxyphenyl)thiazole-4-carbaldehyde, which is sensed by IqsR and modulated by las and PhoB, a phosphate stress response regulator. IQS controls the production of PQS, C4-HSL, and virulence factors, namely, elastase, rhamnolipids, and pyocyanin $[119,125]$. The interconnected QS network in P. aeruginosa is depicted in Figure 2.

P. aeruginosa $\mathrm{QS}$ system possess hierarchical relationships among them with las system in the top position since it regulates other QS systems and $r h l$ at the lowest position as it is regulated by other QS systems to activate QS-related virulence factors. PQS activates $r h l$ and is regulated by las and IQS. IQS controls pqs and rhl systems and is activated by las $[119,126]$. Though the $P$. aeruginosa QS system is an interlinked network, each system can be controlled by several environmental factors including phosphate stress [127], starvation [128], low oxygen [109], low iron [129], and host-derived factors [119,125].

In addition to the above, sigma factors like RpoS and RpoN, global regulators of transcription such as AlgQ, MvaT, DksA, and VfR, and two important homologs of LuxR, namely, QscR and VqsR, are also involved in the regulation of the QS signaling circuit [109]. Among these, the LuxR homolog QscR is an orphan QS control repressor receptor protein that utilizes LasR's signaling molecule since it does not have a synthase enzyme. QscR serves as a negative regulator of the QS system by repressing both las and rhl systems, thus holding a pivotal position in the P. aeruginosa QS system [130,131]. A two-component system, GacS/GacA system is considered as a super-regulator of the QS network and regulates virulence-associated factors production and formation of biofilms [132,133].

Interlink between QS and biofilm formation has been described indirectly by regulation of twitching and swarming motilities, rhamnolipid, and lectin production [62]. Swarming motility, an organized form of surface translocation is useful in the early stages of biofilm development and is regulated by the rhl system $[134,135]$. Twitching motility, a flagella independent way of translocation necessary for microcolony formation is controlled by rhl on Fe-limited minimal medium $[136,137]$.

Rhamnolipids production, which is regulated by $r h l$, is involved in various aspects of biofilm formation such as the formation of microcolonies, maintaining the open channel structure, facilitating mushroom-shaped 3-D structures, and aiding cell dispersion [118,138,139]. The galactophilic lectins LecA and LecB also support biofilm development and are under the control of the rhl system $[140,141]$. 


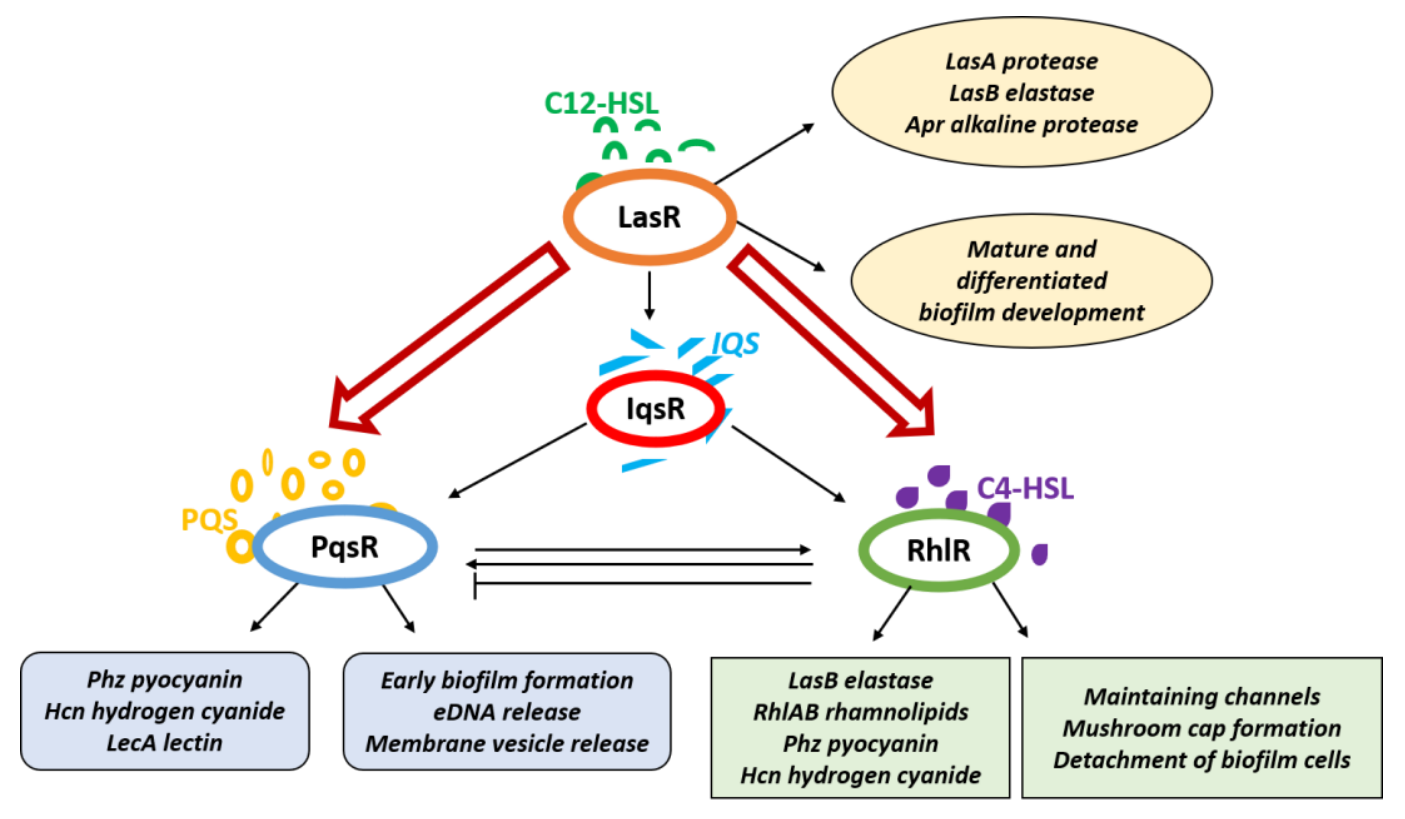

Figure 2. Quorum sensing mechanism of P. aeruginosa.

\section{Pseudomonas aeruginosa Biofilm Challenge to Antimicrobial Agents}

Planktonic cells are at greater risk to the effect of antibiotics and are sufficiently sensitive to antimicrobial agents, whereas bacteria within a biofilm structure are not susceptible to host immune system and antimicrobials as they exhibit a high tolerance and resistance to antimicrobial agents. Most of the resistance mechanisms of microorganisms are transferable and devoid of the target's interaction with antibiotics [36,142].

The biofilm structure of $P$. aeruginosa exhibit a greater extent of antibiotic resistance due to various reasons such as moderate or deficient penetration of antibiotics [143], the altered chemical environment within the biofilm [144], and cell differentiation in a biofilm [145]. All these mechanisms occur due to the multicellular nature of biofilms, thereby leading to antibiotic resistance of biofilm structure and failure in treatment strategies [146,147].

It has become a great challenge to give treatment to patients with infections of $P$. aeruginosa as they exhibit high-level resistance to most of the available antibiotics in use [148]. Recently, World Health Organization (WHO) has mentioned P. aeruginosa as a life-threatening species for which new antibiotics has to be developed to prevent its infections [149]. To date, empirical antibiotic therapy is used to treat cases of P. aeruginosa infections, but more use of antibiotics for therapy may develop multidrug-resistant strains of P. aeruginosa and can cause failure of empirical antibiotic therapy against this microbe [150-152].

P. aeruginosa possesses antibiotic resistance by various mechanisms, namely, intrinsic, acquired, and adaptive resistance mechanisms [153]. The intrinsic resistance includes decreased permeability to the outer membrane, efflux pumps expression, and synthesis of enzymes that inactivate antibiotics, whereas the acquired type of resistance includes mutational changes or horizontal transfer of genes responsible for resistance and the final adaptive resistance is implicated in biofilm formation in the lungs of infected patients that can act as a diffusion barrier to lower antibiotics from reaching the bacterial cells [154].

In addition to the above resistance mechanisms, multidrug-tolerant persister cells can form in the biofilms that withstand antibiotic attacks and cause prolonged periodic infections in individuals with cystic fibrosis [155]. Persisters are a bacterial subpopulation that possess a multidrug tolerance phenotype rather than genetic variations $[156,157]$. Mulcahy et al. [155] have evidenced high levels of persister cells in cystic fibrosis patients compared to wild-type strains of P. aeruginosa, suggesting them as highly antibiotic-resistant and to become multidrug-tolerant [158]. 
Most of the biofilm cells enter the stationary phase with time and persister cells are high in number at this phase. The main reason for decreased susceptibility to antibiotics is that $1 \%$ of the population in the stationary phase becomes tolerant $[159,160]$.

The antibiotic-resistant state of biofilm cells are responsible for human infections by forming biofilms on medical implants such as heart and urinary catheters, heart valves replacements, and implants of joints [161]. They exhibit a serious threat to humans due to their pathogenicity and contribute to a majority of pathogenic infections [162,163]. Based on various observations, Sharma et al. [164] has stated, the multicellular developmental process of the biofilms could be considered for the opening of new targets and approaches to treat antibiotic-resistant microorganisms.

\section{Strategies to Control P. aeruginosa Biofilm Infections}

Increased rates of mortality and morbidity are seen in health care facilities among patients affected by P. aeruginosa infections due to failure in developing new antibiotics and its widespread resistance [165]. The development of new antibiofilm strategies could be effective to treat biofilm-related infections, thereby reducing their complications [166]. The following outlines the different alternative approaches established for fighting infections associated with P. aeruginosa biofilms.

\subsection{Plants as a Natural Source of Antibiofilm Agents for P. aeruginosa Biofilms}

For the past two decades, novel approaches in preventing QS and biofilm formation have been employed by natural products from plants that demonstrate chemo-protective and antimicrobial properties. It is already well known that natural products and herbal remedies have been used in practice by different human cultures for many years for therapy and to prevent the spread of infectious diseases [167]. The following table presents the various natural plant-based products as anti-biofilm agents for treating P. aeruginosa biofilm-associated infections (Table 2).

Table 2. Plant species screened to treat P. aeruginosa biofilms.

\begin{tabular}{|c|c|c|c|c|}
\hline S. No & Plant Species & Plant Part & Extract & References \\
\hline 1 & Allium cepa & Outer scales & Methanol & [168] \\
\hline 2 & Allium sativa & Bulbs & Methanol & {$[168]$} \\
\hline 3 & Ananas comosus & Fruit & Aqueous & [169] \\
\hline 4 & Centella asiatica & Leaves & Ethanol & {$[170]$} \\
\hline 5 & Citrus sinensis & Seeds & Methanol & [168] \\
\hline 6 & Coriandrum sativum & Fruit & Methanol & [168] \\
\hline 7 & Couroupita guianensis & Fruit & Chloroform & {$[171]$} \\
\hline 8 & Elettaria cardamomum & Seeds & Methanol & [168] \\
\hline 9 & Euphorbia hirta L. & Aerial parts & Methanol & {$[172]$} \\
\hline 10 & Garlic & Bulbs & Toluene & {$[173]$} \\
\hline 11 & Hemidesmus indicus (L.) & Root & Ethanol & {$[174]$} \\
\hline 12 & Holarrhena antidysenterica & Bark & Ethanol & {$[174]$} \\
\hline 13 & Laurus nobilis & Leaves & Methanol & [168] \\
\hline 14 & Mangifera indica L. & Seed & Ethanol & {$[174]$} \\
\hline 15 & Manilkara zapota & Fruit & Aqueous & [169] \\
\hline 16 & Mentha longifolia & Aerial part & Methanol & [168] \\
\hline 17 & Musa paradiciaca & Stem & Aqueous & [169] \\
\hline 18 & Ocimum sanctum & Leaves & Aqueous & [169] \\
\hline 19 & Panax notoginseng & Roots & Aqueous & [175] \\
\hline 20 & Psidium guajava & Leaves & Methanol & [168] \\
\hline 21 & Psoralea corylifolia L. & Seeds & Ethanol & {$[174]$} \\
\hline 22 & Senecio brasiliensis & Stem bark & Ethanol/Aqueous & {$[176]$} \\
\hline 23 & Syzygium aromaticum & Bud & Hexane, Chloroform, Methanol & {$[177]$} \\
\hline 24 & Terminalia catappa & Leaves & Methanol & [178] \\
\hline 25 & Amphypterygium adstringens & Stem bark & Hexane & {$[179]$} \\
\hline 26 & Sclerocarya birrea & Stem bark & Methanol & {$[180]$} \\
\hline 27 & Ocimum basilica & Whole plant & Aqueous & [181] \\
\hline 28 & Brassica oleracea & Whole plant & Aqueous & {$[181]$} \\
\hline 29 & Zingiber officinale & Whole plant & Aqueous & {$[181]$} \\
\hline 30 & Myristica cinnamomea & Bark & Methanol & {$[182]$} \\
\hline 31 & Melicope lunu-ankenda & Leaves & Hexane, Chloroform, Methanol & {$[183]$} \\
\hline 32 & Psidium guajava & Leaves & Methanol & [168] \\
\hline
\end{tabular}


Table 2. Cont.

\begin{tabular}{|c|c|c|c|c|}
\hline S. No & Plant Species & Plant Part & Extract & References \\
\hline 33 & Phyllanthus amarus & Whole plant & Hexane, Chloroform, Methanol & [184] \\
\hline 34 & Capparis spinosa & Dried fruit & Methanol & [185] \\
\hline 35 & Thymus sp. & Whole plant & Aqueous & [181] \\
\hline 36 & Nymphaea tetragona & Whole plant & Aqueous & {$[186]$} \\
\hline 37 & Terminalia bellirica & Fruits & Methanol & [187] \\
\hline 38 & Terminalia chebula & Fruits & Methanol & [187] \\
\hline 39 & Syzygium cumini & Seeds & Methanol & {$[187]$} \\
\hline 40 & Sclerocarya birrea & Bark & Methanol & {$[180]$} \\
\hline 41 & Punica granatum L. & Pericarp & Ethanol & [174] \\
\hline 42 & Triumfetta welwitschii & leaves & Dichloromethane: methanol & [188] \\
\hline 43 & Corchorus olitorius & stem & Ethanol & {$[189]$} \\
\hline 44 & Phrynium capitatum & Leaves & Ethanol & [190] \\
\hline 45 & Dryptes indica & Leaves & Ethanol & {$[190]$} \\
\hline 46 & Plantain herb & Whole plant & Ethanol & [191] \\
\hline 47 & Cinnamomum camphora & Bark & Distilled water & [192] \\
\hline 48 & Centella asiatica & Leaves & Ethanol & [170] \\
\hline 49 & Anogeissus acuminata & Whole plant & Methanol & [193] \\
\hline 50 & Mallotus roxburghianus Muell & Whole plant & Ethanol & [193] \\
\hline 51 & Camellia kissi wall. & Leaves & Methanol & [194] \\
\hline 52 & Plectranthus tenuiflorus & Leaves & Methanol & [195] \\
\hline 53 & Persicaria maculosa & Aerial parts & Ethanol & {$[196]$} \\
\hline 54 & Bistorta officinalis & Rhizome & Ethanol & [196] \\
\hline 55 & Syzygium legatii & Leaves & Acetone & {$[197]$} \\
\hline 56 & Syzygium masukuense & Leaves & Acetone & [197] \\
\hline 57 & Syzygium species $A$ & Leaves & Acetone & [197] \\
\hline 58 & Berginia ciliate & rhizome with skin & Methanol & [198] \\
\hline 59 & Lavandulacoronopifolia & aerial parts & Methanol: water & [199] \\
\hline 60 & Centella asiatica & Leaves & Methanol & [200] \\
\hline 61 & Mentha spicata & Leaves & Methanol & [200] \\
\hline 62 & Azadirachta indica & Leaves & Methanol & [200] \\
\hline 63 & Psidium guajava & Leaves & Methanol & [200] \\
\hline 64 & Syzygium aromaticum & Whole part & Ethyl acetate & [200] \\
\hline 65 & Cinnamomum zeylanicum & Whole part & Ethyl acetate & [200] \\
\hline
\end{tabular}

\subsection{Enzymes against P. aeruginosa Biofilms}

Another possible approach to control biofilms is the incorporation of enzymes to destroy polymers of the extracellular matrix and enable disruption of biofilms [166]. As biofilm matrix is a complex architecture, multi enzymatic formulations are needed to control biofilms effectively. Researchers have reported a variety of enzymes that can fight against $P$. aeruginosa biofilms [201].

A study conducted by Kovach et al. [202] reported that the effect of EPS-specific enzymes, namely, alginate lyase and DNase is greater on P. aeruginosa biofilms, whereas non-specific enzymes such as glycoside hydrolases, cellulases, and $\alpha$-amylases did not significantly alter the biofilm mechanics in vitro. However, the mechanism of how these enzymes hinder the biofilm mechanism remains still unknown. In case of in vivo studies on a mouse model of wound infections, glycoside hydrolases were more productive than other specific enzymes since there might be a difference in the formation of biofilms developed in vivo and in vitro by genetically similar strains of bacteria.

Quorum quenching was initially described in 2000 with the invention of a quorum quenching enzyme from Erwinia carotovora that degrade AHL signals. Most of the identified quorum quenching enzymes namely phosphotriesterase-like lactonases (PLLs), lactonases, acylases, and oxidoreductases target AHLs [203-205]. Example of enzymes that can act as anti-biofilm agents for grafting of wounds and removes barriers that weaken wound healing, such as weakened tissues, bacterial biofilms, and scars, include bromelain derived debridase, collagenase, trypsin, fibrinolysin, lysozyme, streptokinase, and dispersin B [206-210]. Different classes of the enzyme known to control biofilms are shown in Table 3. 
Table 3. Classes of enzymes used in controlling P. aeruginosa biofilms.

\begin{tabular}{cccc}
\hline Class of Enzyme & Example & Target & References \\
\hline Oxidoreductases & Glucose oxidase, Curvularia & $\begin{array}{c}\text { Directly or indirectly retarding bacterial } \\
\text { growth by production of } \mathrm{H}_{2} \mathrm{O}_{2}\end{array}$ & [211,212] \\
Transferases & Transaminase & EPS matrix & [213] \\
Hydrolases & AiiA, $\alpha$-amylase, Proteinase K & QS molecules, Exopolysaccharides, & {$[203,214,215]$} \\
Lyases & Alginate lyase & Exoproteins & [216] \\
\hline
\end{tabular}

Acylase reduces P. aeruginosa ATCC 10145 and PAO1 growth to $60 \%$ by disrupting QS signaling [217,218]. A study by Vogel et al. [219] states immobilizing quorum quenching enzyme with quorum quenching properties such as acylase PvdQ over the polydimethylsiloxane silicone (PDMS) surface in a biosensor setup exhibited a 6-fold decrease of the auto-inducer 3-oxo-C12 compared to untreated material.

Researchers have stated enzymes namely lysozyme and proteinase $\mathrm{K}$ could inhibit the biofilm formation of many species of bacteria [220-222]. In connection to this, Eladawy et al. [223] reported lysozyme as an potent biofilm inhibitor as it reduces $19 \%$ biofilm formation at a physiological concentration of $30 \mu \mathrm{g} / \mathrm{mL}$, whereas proteinase $\mathrm{K}$ exhibited a biphasic effect on P. aeruginosa biofilms at different concentrations. Another class of enzyme, BpiB09 oxidoreductases, were evidenced to reduce the motility of bacteria, biofilm formation, production of pyocyanin, and prevent the induction of $\mathrm{N}$-(3-oxododecanoyl)-L-homoserine lactone in P. aeruginosa PA01 strains [224].

Dioxygenases destroy 2-heptyl-3-hydroxy-4 $(1 \mathrm{H})$ quinolone-based signaling molecules and have been shown to inhibit the quinolone signals in the P. aeruginosa QS system $[225,226]$. Banar et al. [227] studied the mechanism of $\beta$-glucosidase and lyticase enzymes on biofilms formed by various strains of $P$. aeruginos $a$ and found that both enzymes degraded and altered the biofilm states. These enzymes also significantly reduced the colony-forming units and revealed no cytotoxicity when treated against cell lines of A-549 human lung carcinoma and A-431 human epidermoid carcinoma.

Another study by Daboor et al. [228] has revealed that alginate lyase (AlyP1400), a class of alginolytic enzyme purified from marine bacteria Pseudoalteromonas sp., reduced the $P$. aeruginosa biofilms after $24 \mathrm{~h}$ of incubation by $69 \%$ and could serve as a specific combinational therapeutic strategy when used along with conventional antibiotics. A lactonase group of quorum quenching enzyme, SsoPox-W263I reduces protease, elastase, and pyocyanin production among bacteriophage resistant strains or ten antibiotics and degrade acyl-homoserine lactones [229].

Snarr et al. [230] reported microbial glycoside hydrolases developed by recombinant technology may serve as a potent therapeutic agent with promising antibiofilm potential by destroying biofilms and inhibiting virulence. An enzyme-based endoscope cleaner was invented for clearing biofilms in medical devices by Stiefel et al. [231] using optimized selected base formulation of enzyme mixture consisting of polysaccharides, protease, and other enzymes, which removed about $90 \%$ of biofilms formed by P. aeruginosa in 96 -well plate with $>99 \%$ decrease of $\mathrm{CFU}$ and $>90 \%$ decrease in extracellular polymeric substances.

A study on trypsin, $\alpha$-mannosidase, and $\beta$-mannosidase enzymes effect on P. aeruginosa biofilm from wound infections caused due to burns by Banar et al. [232] proved only enzyme trypsin had no cytotoxic effect on cell lines of A-431 human epidermoid carcinoma and possessed features better than other enzymes, evidencing trypsin as a potential antibiofilm agent for treating burn wound infections of $P$. aeruginosa.

The only enzyme that is found to disrupt $P$. aeruginosa biofilms in clinical fields is Dornasealfa (deoxyribonuclease I), which promotes destruction by eDNA hydrolyzation within the extracellular matrix [233,234]. However, immature P. aeruginosa biofilms are more prone and sensitive when treated with deoxyribonuclease I than the mature biofilms [43,235]. Another therapeutic enzyme, glycoside hydrolase DspB (Dispersin B), hydrolyze the poly-b-1,6-N-acetyl-D-glucosamine (PNAG/PIA) exopolysaccharide found 
in biofilms [206,207,236], but this PNAG is not found in P. aeruginosa biofilms [237-239]. Baker et al. [240] identified naturally derived glycoside hydrolases, namely, PelAh and PslGh that specifically target psl and pel polysaccharides, which can clear in vitro biofilms of clinical, environmental, and laboratory isolates at nanomolar concentrations.

A study by Kiran et al. [241] says lactonase treatment on P. aeruginosa biofilms significantly quenches all the major lactones synthesized by $P$. aeruginosa strains such as 3-oxo-C12-HSL and C4-HSL, which regulates virulence factor expression. In addition, extracellular hydrolases secreted by mucoid $P$. aeruginosa strains during biofilm growth EstA, LasB, and LipC can cause changes in the composition of EPS and alter the motility of cells as reported by Tielen et al. [242].

One of the main drawbacks of enzyme-mediated antibiofilm therapy is that it should be carried out in combination with antibiotic agents as it may become a preventive measure rather than a way of treatment. Another concern is their typical higher cost when compared to other costs of conventional chemical disinfectants and antimicrobial agents. But apart from this, many researchers have reported that biofilm matrix-degrading enzymes could be a potent antibiofilm agent to reduce the incidence of medical device infections [243].

\subsection{In Silico Approach to Control P. aeruginosa Biofilms}

Many studies have reported various chemical tools to exploit new knowledge to inhibit bacterial virulence by hindering the QS systems as a novel means to reduce $P$. aeruginosa infections efficiently, which makes it harder for the bacteria to develop drug resistance. Wang et al. [244] identified cladodionen, isolated from extracts of the marine fungal strain Cladosporium sp. Z148 as a novel QS inhibitor that showed effective binding conformation to LasR and PqsR compared to native ligands through molecular docking approach. He also reported that the QS-related mRNA gene expressions were down-regulated by cladodionen. A recent study by Sadiq et al. [245] reported sulfamerazine, a synthetic FDA-approved compound as an inhibitor of LasR by performing virtual screening and molecular docking by employing a pharmacophore hypothesis based screening and elucidating the stability of their binding conformation by a simulation study. A study by Baldelli et al. [246] suggested two antibiotic compounds, namely, nitrofurazone and erythromycin estolate as PqsE inhibitors by screening a library of FDA-approved drugs and found that these compounds reduce the expression of PqsE-dependent virulence and formation of biofilm in P. aeruginosa PAO1 model strain.

Abelyan et al. [247] through in silico virtual screening approach reported benzamides, a synthetic derivative of flavones, could be promising LasR inhibitors as they exhibit higher binding affinity to the LasR ligand-binding domain compared to the DNA binding domain. Also, the selected compounds conformationally binds to the same amino acid residues of the ligand-binding region similar to the natural ligand, which indicated the competitive nature of the compounds. Mellini et al. [248] attempted a virtual screening on in silico FDA-approved drugs library consisting of 1467 compounds through molecular docking and selected five top hit compounds that possessed a stable binding affinity for the QS receptor PqsR as novel antagonists of the pqs system which imparts its effect on P. aeruginosa PqsR associated expression of virulence factors.

Another report by Shah et al. [249] found a synthetic compound potassium 2-methoxy4-vinylphenolate to be the most powerful $P$. aeruginosa quorum-sensing inhibitor that targets LasIR/RhlIR circuits and inhibits the formation of biofilm, production of virulenceassociated factors like LasA protease, pyocyanin, LasB elastase, and motilities in bacteria. Recently, a study by Nain et al. [250] utilized energy-optimized pharmacophore coupled virtual screening to discover QS inhibitors for LasR of P. aeruginosa based on hydrogen bond networking and further exploited the stability of the binding complexes through a dynamics simulation study. Singh and Bhatia [251] performed a study on an FDAapproved clinical drug, Albendazole, by a structure-based molecular docking approach that exhibited putative interactions with LasB and CviR receptor protein of P. aeruginosa and Chromobacterium violaceum, respectively. 
Paczkowski et al. [252] screened a highly diverse library of chemical compounds consisting of 60,000 molecules to identify putative flavone-based QS inhibitors. The structureactivity relationship analysis reported that flavone A ring backbone with two hydroxyl moieties is necessary for LasR/RhlR inhibition and thus stated as flavonoids might function in a non-competitive way to hinder LasR/RhlR DNA-binding by altering the transcriptional regulation of quorum sensing mediated target promoters and thereby leading to a decrease in the production of virulence factors. An in silico approach with combined pharmacophore and molecular docking studies was carried out by $\mathrm{Xu}$ et al. [253] for screening a library of 167,740 compounds derived from the Specs database for potent QscR agonists and LasR antagonists since QscR is an indirect suppressor and represses the las system by binding to the promoter region of LasI or forming an inactive heteromultimer with LasR. Concerning this mechanism, it was suggested that QscR agonists and LasR antagonists can have synergistic effects which led to the identification of four potential compounds as biofilm inhibitors with novel scaffolds.

A report by Jha et al. [254] stated a high throughput computational docking approach to identify an inhibitor for LasR of P. aeruginosa and suggested [(4E)-1-hydroxy-3methylpyridin- $4(1 \mathrm{H})$-ylidene]azinic acid] as the best antagonist of LasR as it satisfied the ADMET profile for drug properties among the top five inhibitors obtained post the screening process. Tan et al. [255] discovered novel QSI candidates using 3040 structures of natural compounds and their derivatives by a structure-based virtual screening (SB-VS) protocol and found five compounds to have the efficiency to block QS-associated expression of genes in P. aeruginosa utilizing a live reporter gene assay.

Wei et al. [256] designed a computational network to measure cell-cell interactions directly and dynamics of biofilm at a fundamental level, which revealed the quorum sensing inhibitor (QSI)-based therapies to decrease the spread of QSI resistance through simulations. Sharma et al. [257] reported a web server, dPABBS, which could predict, and design anti-biofilm peptides based on the whole composition of amino acid residues, selected features of residue, and positional preference of amino acid residues to fight $P$. aeruginosa biofilms. Another interesting piece of research by Kim et al. [258] found 6-gingerol from fresh ginger, a pungent oil, antagonizes P. aeruginosa $\mathrm{QS}$ receptors through hydrogen bonding and hydrophobic interactions with LasR as revealed by molecular docking analysis. Supporting the above information, transcriptomics analysis also proved that 6-gingerol repressed QS-induced genes, particularly virulence factor production.

Using a bio-sensor strain of P. aeruginosa, Gopu et al. [259] reported quercetin as a competitive inhibitor of LasR through in silico methods, namely molecular docking and simulation studies. A system-level approach was carried out to quantify the capacity of biofilm formation by mutants for identifying the target genes necessary for metabolism in the planktonic state of bacteria. It was seen that the essential gene mutation treatment made P. aeruginosa survive by regulating the metabolism of acetate, arginine, and glutamate [260].

Computational methods employ a crucial role in the current drug discovery process starting from designing and maintenance of small molecule libraries, improvisation of pharmacological properties of the lead compounds to the final stage in clinical development. Thus, in silico methods could be a productive approach and form alternative tools in all stages of drug development for efficacy, safety, speed with more certainty, and lower cost [261]. On the other side, though several QS inhibitors have been identified so far, much of them do not suit further drug development as lead compounds because of their undesirable pharmacological properties and cytotoxicity [248]. Also, much of the literature on computational approaches have resulted in lead compounds but does not provide further experimental validation of their biological activity [262].

In addition, molecules identified by the virtual screening approach might be false positives resulting from molecule aggregation and could be considered as "promiscuous inhibitors" if they have not been properly investigated by in vitro experimental verifications. For many years, the concept of computational studies has come into play after the synthesis of molecules and a significant illustration of the data. However, now predictions 
are made for pharmacological activity without in vitro or in vivo validation. In such a case, it is important to understand predictive models only have a limited prediction domain and they are not very accurate and reliable [263].

\title{
8. Conclusions
}

Members of most Pseudomonas species readily form biofilms and remain as a causative organism for biofilm-mediated ailments leading to the development of recurrent infections and chronic infectious diseases. In connection to this, the opportunistic pathogen $P$. aeruginosa in its mucoid state grabs attention in the research area because of its association with biofilm formation. One of the major drawbacks in the treatment of these biofilm-related infections is its wide spectrum resistance to antibiotic treatments that already exist. Hence, in this review, we have summarized the process and mechanisms intricated in biofilm formation by P. aeruginosa and the various possibilities so far identified to treat these biofilms effectively. In recent years, several investigations and strategies exploited to study the underlying mechanism of biofilm formation and to control its pathogenesis have been demonstrated. However, significantly more optimal methods utilizing advanced techniques are still needed to identify a more efficient antibiofilm agent to treat P. aeruginosa-associated infections, as they are complex and difficult to treat with ease.

Author Contributions: Conceptualization, R.M.; Writing-original draft preparation, A.V., P.V., and M.R.; Writing-review and editing, S.N., S.A. and G.-S.K. All authors have read and agreed to the published version of the manuscript.

Funding: This research received no external funding.

Institutional Review Board Statement: Not applicable.

Informed Consent Statement: Not applicable.

Data Availability Statement: Not applicable.

Conflicts of Interest: The authors declare no conflict of interest.

\begin{abstract}
Abbreviations
QS-Quorum Senisng; EPS-Extracellular Polymeric Substances; eDNA-Extracellular DNA; NIH-National Institute of Health; AI-2-Autoinducer-2; AHL-Acyl Homoseine Lactone; PQS- Pseudomonas Quinolone Signal; IQS-Integrated Quorum Sensing; 3-oxo-C12-HSL-N-(3-oxododecanoyl)-L-homoserine lactone; C4-HSL-N-butanoyl-L-homoserine lactone; WHO-World Health Organization; PLL-Phosphotriesteraselike lactonases; PDMS-Polydimethylsiloxane silicone; CFU-Colony Forming Unit; DspB-Dispersin B; PNAG-Poly-b-1,6-N-acetyl-D-glucosamine; LBD-Ligand Binding Domain; SBVS-Structure Based Virtual Screening; QSI-Quorum Sensing Inhibitor.
\end{abstract}

\section{References}

1. Harmsen, M.; Yang, L.; Pamp, S.J.; Tolker-Nielsen, T. An update on Pseudomonas aeruginosa biofilm formation, tolerance, and dispersal. FEMS Immunol. Med. Microbiol. 2010, 59, 253-268. [CrossRef] [PubMed]

2. Li, X.; Lee, J. Antibiofilm agents: A new perspective for antimicrobial strategy. J. Microbiol. 2017, 55, 753-766. [CrossRef] [PubMed]

3. Moradali, M.F.; Ghods, S.; Rehm, B.H.A. Pseudomonas aeruginosa lifestyle:A paradigm for adaptation, survival, and persistence. Front. Cell. Infect. Microbiol. 2017, 7, 39. [CrossRef] [PubMed]

4. Prakash, B.; Veeregowda, B.M.; Krishnappa, G. Biofilms: A survival strategy of bacteria. Curr. Sci. 2003, 85, 1299-1307.

5. Stoodley, P.; Sauer, K.; Davies, D.G.; Costerton, J.W. Biofilms as complex differentiated communities. Annu. Rev. Microbiol. 2002, 56, 187-209. [CrossRef]

6. Costerton, J.W.; Stewart, P.S.; Greenberg, E.P. Bacterial biofilms: A common cause of persistent infections. Science 1999, 284, 1318-1322. [CrossRef]

7. Fux, C.A.; Costerton, J.W.; Stewart, P.S.; Stoodley, P. Survival strategies of infectious biofilms. Trends Microbiol. 2005, 13, 34-40. [CrossRef]

8. Flemming, H.; Wingender, J. The biofilm matrix. Nat. Rev. Microbiol. 2010, 8, 623-633. [CrossRef]

9. Häussler, S.; Parsek, M.R. Biofilms 2009: New perspectives at the heart of surface-associated microbial communities. J. Bacteriol. 2010, 192, 2941-2949. [CrossRef] 
10. Schwartz, T.; Jungfer, C.; Heisler, S.; Friedrich, F.; Faubel, W.; Obst, U. Combined use of molecular biology taxonomy, Raman spectrometry, and ESEM imaging to study natural biofilms grown on filter materials at waterworks. Chemosphere 2009, 77, 249-257. [CrossRef]

11. Lee, J.; Kim, Y.; Ryu, S.Y.; Cho, M.H.; Lee, J. Ginkgolic acids and Gingko biloba extract inhibit Escherichia coli O157: H7 and Staphylococcus aureus biofilm formation. Int. J. Food Microbiol. 2014, 174, 47-55. [CrossRef]

12. Wolcott, R.; Costerton, J.W.; Raoult, D.; Cutler, S.J. The polymicrobial nature of biofilm infection. Clin. Microbiol. Infect. 2013, 19, 107-112. [CrossRef]

13. Yang, L.; Liu, Y.; Wu, H.; Hóiby, N.; Molin, S.; Song, Z. Current understanding of multi species biofilms. Int. J. Oral Sci. 2011, 3, 74-81. [CrossRef] [PubMed]

14. Donlan, R.M.; Costerton, J.W. Biofilms: Survival mechanisms of clinically relevant microorganisms. Clin. Microbiol. Rev. 2002, 15, 167-193. [CrossRef] [PubMed]

15. Römling, U.; Balsalobre, C. Biofilm infections, their resilience to therapy and innovative treatment strategies. J. Intern. Med. 2012, 272, 541-561. [CrossRef] [PubMed]

16. Høiby, N.; Bjarnsholt, T.; Givskov, M.; Molin, S.; Ciofu, O. Antibiotic resistance of bacterial biofilms. Int. J. Antimicrob. Agents 2010, 35, 322-332. [CrossRef] [PubMed]

17. Fernández, L.; Briedenstein, E.B.M.; Hancock, R.E.W. Creeping baselines and adaptive resistance to antibiotics. Drug Resist. Updates 2011, 14, 1-21. [CrossRef] [PubMed]

18. Francolini, I.; Donelli, G. Prevention and control of biofilm-based medical-device-related infections. FEMS Immunol. Med. Microbiol. 2010, 59, 227-238. [CrossRef]

19. Mermel, L.A.; Farr, B.M.; Sherertz, R.J.; Raad, I.I.; O' Grady, N.; Harris, J.S.; Craven, D.E. Guidelines for the management of intravascular catheter-related infections. Clin. Infect. Dis. 2001, 32, 1249-1272. [CrossRef] [PubMed]

20. Klevens, R.M. Invasive methicillin-resistant Staphylococcus aureus infections in United States. JAMA 2007, $298,1763-1771$. [CrossRef]

21. Flores-Mireles, A.L.; Walker, J.N.; Caparon, M.G.; Hultgren, S.J. Urinary tract infections: Epidemiology, mechanisms of infection and treatment options. Nat. Rev. Genet. 2015, 13, 269-284. [CrossRef]

22. Pinto, H.; Simões, M.; Borges, A. Prevalence and impact of biofilms on bloodstream and urinary tract infections:A systematic review and meta-analysis. Antibiotics 2021, 10, 825. [CrossRef]

23. Wenzel, R.P.; Edmond, M.B. The impact of hospital-acquired bloodstream infections. Emerg. Infect. Dis. 2001, 7, 174-177. [CrossRef]

24. Bryers, J.D. Medical biofilms. Biotechnol. Bioeng. 2008, 100, 1-18. [CrossRef] [PubMed]

25. Wenzel, R.P. Health care-associated infections: Major issues in the early years of the 21st century. Clin. Infect. Dis. 2007, 45 (Suppl. 1), S85-S88. [CrossRef] [PubMed]

26. Zobell, C.E. The effect of solid surfaces upon bacterial activity. J. Bacteriol. 1943, 46, 39-56. [CrossRef] [PubMed]

27. Maukonen, J.; Mättö, J.; Wirtanen, G.; Raaska, L.; Mattila-Sandholm, T.; Saarela, M. Methodologies for the characterization of microbes in industrial environments: A review. J. Ind. Microbiol. Biotechnol. 2003, 30, 327-356. [CrossRef] [PubMed]

28. Sihorkar, V.; Vyas, S.P. Biofilm consortia on biomedical and biological surfaces: Delivery and targeting strategies. Pharm. Res. 2001, 18, 1247-1254. [CrossRef]

29. Jakobsen, T.H.; Bjarnsholt, T.; Jensen, P.Ø.; Givskov, M.; Høiby, N. Targeting quorum sensing in Pseudomonas aeruginosa biofilms: Current and emerging inhibitors. Future Microbiol. 2013, 8, 901-921. [CrossRef]

30. Rahim, K.; Saleha, S.; Basit, A.; Zhu, X.; Ahmed, I.; Huo, L.; Zhang, P.; Usman, B.; Munir, S.; Franco, O.L. Pseudomonas aeruginos as a powerful biofilm producer and positive action of amikacin against isolates from chronic wounds. Jundishapur. J. Microbiol. 2017, 10, e57564. [CrossRef]

31. Wojtyczka, R.D.; Orlewska, K.; Kępa, M.; Idzik, D.; Dziedzic, A.; Mularz, T.; Krawczyk, M.; Miklasińska, M.; Wąsik, T.J. Biofilm formation and antimicrobial susceptibility of Staphylococcus epidermidis strains from a hospital environment. Int. J. Environ. Res. Public Health 2014, 11, 4619-4633. [CrossRef]

32. Lebeaux, D.; Ghigo, J. Management of biofilm-associated infections: What can we expect from recent research on biofilm lifestyles? Med. Sci. 2012, 28, 727-739.

33. Lerch, T.Z.; Chenu, C.; Dignac, M.F.; Barriuso, E.; Mariotti, A. Biofilm vs. Planktonic lifestyle: Consequences for pesticide 2,4-D metabolism by Cupriavidus necator. Front. Microbiol. 2017, 8, 904. [CrossRef]

34. McCarty, S.; Woods, E.; Percival, S.L. Biofilms: From Concept to Reality; Elsevier Inc.: Amsterdam, The Netherlands, 2014.

35. Fagerlind, M.G.; Webb, J.S.; Barraud, N.; McDougald, D.; Jansson, A.; Nilsson, P.; Harlén, M.; Kjelleberg, S.; Rice, S.A. Dynamic modelling of cell death during biofilm development. J. Theor. Biol. 2012, 295, 23-36. [CrossRef] [PubMed]

36. Olivares, E.; Badel-Berchoux, S.; Provot, C.; Prévost, G.; Bernardi, T.; Jehl, F. Clinical impact of antibiotics for the treatment of Pseudomonas aeruginosa biofilm infections. Front. Microbiol. 2020, 10, 2894. [CrossRef] [PubMed]

37. Dufour, D.; Leung, V.; Lévesque, C.M. Bacterial biofilm: Structure, function, and antimicrobial resistance. Endod. Topics 2010, 22, 2-16. [CrossRef]

38. Jamal, M.; Ahmad, W.; Andleeb, S.; Jalil, F.; Imran, M.; Nawaz, M.A.; Hussain, T.; Ali, M.; Rafiq, M.; Kamil, M.A. Bacterial biofilm and associated infections. J. Chin. Med. Assoc. 2018, 81, 7-11. [CrossRef] 
39. Limoli, D.H.; Jones, C.J.; Wozniak, D.J. Bacterial extracellular polysaccharides in biofilm formation and function. Microbiol. Spectr. 2015, 3, 1-30. [CrossRef] [PubMed]

40. Annous, B.A.; Fratamico, P.M.; Smith, J.L. Quorum sensing in biofilms: Why bacteria behave the way they do. J. Food Sci. 2009, 74, 24-37. [CrossRef]

41. Flemming, H.; Neu, T.R.; Wozniak, D.J. The EPS matrix: The "house of biofilm cells". J. Bacteriol. 2007, 189, 7945-7947. [CrossRef]

42. Hausner, M.; Wuertz, S. High rates of conjugation in bacterial biofilms as determined by quantitative in situ analysis. Appl. Environ. Microbiol. 1999, 65, 3710-3713. [CrossRef]

43. Whitchurch, C.B.; Tolker-Nielsen, T.; Ragas, P.C.; Mattick, J.S. Extracellular DNA required for bacterial biofilm formation. Science 2002, 295, 1487. [CrossRef]

44. del Pozo, J.L.; Patel, R. The challenge of treating biofilm-associated bacterial infections. Clin. Pharmacol. Ther. 2007, 82, 204-209. [CrossRef]

45. Khatoon, Z.; McTierman, C.D.; Suuronen, E.J.; Mah, T.F.; Alarcon, E.I. Bacterial biofilm formation on implantable devices and approaches to its treatment and prevention. Heliyon 2018, 4, 201067. [CrossRef]

46. Srivastava, S.; Bhargava, A. Biofilms and human health. Biotechnol. Lett. 2016, 38, 1-22. [CrossRef]

47. Azeredo, J.; Azevedo, N.F.; Briandet, R.; Cerca, N.; Coenye, T.; Costa, A.R.; Desvaux, M.; Bonaventura, G.D.; Hébraud, M.; Jaglic, Z.; et al. Critical review on biofilm methods. Crit. Rev. Microbiol. 2017, 43, 313-351. [CrossRef]

48. Turan, O.; Deirel, Y.; Day, S.; Tezdogan, T. Experimental determination of added hydrodynamic resistance caused by marine biofouling on ships. In Proceedings of the 6th European Transport Research Conference, Warsaw, Poland, 18-21 April 2016; pp. $1-10$.

49. Abdel-Aziz, S.M.; Aeron, A. Bacterial biofilm: Dispersal and inhibition strategies. SAJ Biotechnol. 2014, 1, 105. [CrossRef]

50. Chen, M.; Yu, Q.; Sun, H. Novel strategies for the prevention and treatment of biofilm related infections. Int. J. Mol. Sci. 2013, 14, 18488-18501. [CrossRef] [PubMed]

51. Chang, C.Y. Surface sensing for biofilm formation in Pseudomonas aeruginosa. Front. Microbiol. 2017, 8, 2671. [CrossRef] [PubMed]

52. Balasubramanian, D.; Schneper, L.; Kumari, H.; Mathee, K. A dynamic and intricate regulatory network determines Pseudomonas aeruginosa virulence. Nucleic Acids Res. 2013, 41, 1-20. [CrossRef] [PubMed]

53. Streeter, K.; Katouli, M. Pseudomonas aeruginosa: A review of their pathogenesis and prevalence in clinical settings and the environment. Infect. Epidemiol. Med. 2016, 2, 25-32. [CrossRef]

54. Mantero, M.; Gramegna, A.; Pizzamiglio, G.; D'Adda, A.; Tarsia, P.; Blasi, F. Once daily aerosolised tobramycin in adult patients with cystic fibrosis in the management of Pseudomonas aeruginosa chronic infection. Multidiscip. Respir. Med. 2017, 12, 2. [CrossRef]

55. Davis, R.; Brown, P.D. Multiple antibiotic resistance index, fitness and virulence potential in respiratory Pseudomonas aeruginosa from Jamaica. J. Med. Microbiol. 2016, 65, 261-271. [CrossRef]

56. Valderrey, A.D.; Pozuelo, M.J.; Jiménez, P.A.; Maciá, M.D.; Oliver, A.; Rotger, R. Chronic colonization by Pseudomonas aeruginosa of patients with obstructive lung diseases: Cystic fibrosis, bronchiectasis, and chronic obstructive pulmonary disease. Diagn. Microbiol. Infect. Dis. 2010, 68, 20-27. [CrossRef]

57. Kerr, K.G.; Snelling, A.M. Pseudomonas aeruginosa: A formidable and ever-present adversary. J. Hosp. Infect. 2009, 73, 338-344. [CrossRef]

58. Hidron, A.I.; Edwards, J.R.; Patel, J.; Horan, T.C.; Sievert, D.M.; Pollock, D.A.; Fridkin, S.K.; National Healthcare Safety Network Team; Participating National Healthcare Safety Network Facilities. NHSN annual update: Antimicrobial-resistant pathogens associated with healthcare associated infections: Annual summary of data reported to the National Healthcare Safety Network at the centers for disease control and prevention, 2006-2007. Infect. Control Hosp. Epidemiol. 2008, 29, 996-1011. [CrossRef]

59. Strateva, T.; Mitov, I. Contribution of an arsenal of virulence factors to pathogenesis of Pseudomonas aeruginosa infections. Ann. Microbiol. 2011, 61, 717-732. [CrossRef]

60. Ghafoor, A.; Hay, I.D.; Rehm, B.H.A. Role of exopolysaccharides in Pseudomonas aeruginosa biofilm formation and architecture. Appl. Environ. Microbiol. 2011, 77, 5238-5246. [CrossRef] [PubMed]

61. Ryder, C.; Byrd, M.; Wozniak, D.J. Role of polysaccharides in Pseudomonas aeruginosa biofilm development. Curr. Opin. Microbiol. 2007, 10, 644-648. [CrossRef] [PubMed]

62. Rasamiravaka, T.; Labtani, Q.; Duez, P.; El Jaziri, M. The formation of biofilms by Pseudomonas aeruginosa: A review of the natural and synthetic compounds interfering with control mechanisms. Biomed. Res. Int. 2015, 759348, 759348. [CrossRef] [PubMed]

63. Ma, L.; Wang, J.; Wang, S.; Anderson, E.M.; Lam, J.S.; Parsek, M.R.; Wozniak, D.J. Synthesis of multiple Pseudomonas aeruginosa biofilm matrix exopolysaccharides is post transcriptionally regulated. Environ. Microbiol. 2012, 14, 1995-2005. [CrossRef] [PubMed]

64. Colvin, K.M.; Gordon, V.D.; Murakami, K.; Borlee, B.R.; Wozniak, D.J.; Wong, G.C.L.; Parsek, M.R. The pel polysaccharide can serve a structural and protective role in the biofilm matrix of Pseudomonas aeruginosa. PLoS Pathog. 2011, 7, e1001264. [CrossRef]

65. Franklin, M.J.; Nivens, D.E.; Weadge, J.T.; Howell, P.L. Biosynthesis of the Pseudomonas aeruginosa extracellular polysaccharides, alginate, Pel, and Psl. Front. Microbiol. 2011, 167, 1-16. [CrossRef]

66. Mulcahy, H.; Charron-Mazenod, L.; Lewenza, S. Pseudomonas aeruginosa produces an extracellular deoxyribonuclease that is required for utilization of DNA as a nutrient source. Environ. Microbiol. 2010, 12, 1621-1629.

67. Hengge, R. Principles of c-di-GMP signalling in bacteria. Nat. Rev. Microbiol. 2009, 7, 263-273. [CrossRef] [PubMed] 
68. Lee, V.T.; Matewish, J.M.; Kessler, J.L.; Hyodo, M.; Hayakawa, Y.; Lory, S. A cyclic-di-GMP receptor required for bacterial exopolysaccharide production. Mol. Microbiol. 2007, 65, 1474-1484. [CrossRef]

69. Byrd, M.S.; Sadovskaya, I.; Vinogradov, E.; Lu, H.; Sprinkle, A.B.; Richardson, S.H.; Ma, L.; Ralston, B.; Parsek, M.R.; Anderson, E.M.; et al. Genetic and biochemical analysis of Pseudomonas aeruginosa Psl exopolysaccharide reveal overlapping roles for polysaccharide synthesis enzymes in Psl and LPS production. Mol. Microbiol. 2009, 73, 622-638. [CrossRef]

70. Stover, C.K.; Pham, X.Q.; Erwin, A.L.; Mizoguchi, S.D.; Warrener, P.; Hickey, M.J.; Brinkman, F.S.; Hufnagle, W.O.; Kowalik, D.J.; Lagrou, M.; et al. Complete genome sequence of Pseudomonas aeruginosa PAO1, an opportunistic pathogen. Nature 2000, 406, 959-964. [CrossRef]

71. Regni, C.; Tipton, P.A.; Beamer, L.J. Crystal structure of PMM/PGM: An enzyme in the biosynthetic pathway of P. aeruginosa virulence factors. Structure 2002, 10, 269-279. [CrossRef]

72. Fritz, T.A.; Hurley, J.H.; Trinh, L.B.; Shiloach, J.; Tabak, L.A. The beginnings of mucin biosynthesis: The crystal structure of UDP-GalNAc:polypeptide alpha-Nacetylgalactosaminyltransferase- T1. Proc. Natl. Acad. Sci. USA 2004, 101, 15307-15312. [CrossRef] [PubMed]

73. Ramelot, T.A.; Yee, A.; Cort, J.R.; Semesi, A.; Arrowsmith, C.H.; Kennedy, M.A. NMR structure and binding studies confirmthat PA4608 from Pseudomonas aeruginosa is a PilZ domain and a c-di-GMP binding protein. Proteins 2007, 66, 266-271. [CrossRef] [PubMed]

74. Keiski, C.L.; Harwich, M.; Jain, S.; Neculai, A.M.; Yip, P.; Robinson, H.; Whitney, J.C.; Riley, L.; Burrows, L.L.; Ohman, D.E.; et al. AlgK is a TPR-containing protein and the periplasmic component of a novel exopolysaccharide secretin. Structure 2010, 18, 265-273. [CrossRef] [PubMed]

75. Rozeboom, H.J.; Bjerkan, T.M.; Kalk, K.H.; Ertesvag, H.; Holtan, S.; Aachmann, F.L.; Valla, S.; Dijkstra, B.W. Structural and mutational characterization of the catalytic A-module of the mannuronan C-5-epimerase AlgE4 from Azotobacter vinelandii. J. Biol. Chem. 2008, 283, 23819-23828. [CrossRef]

76. Molgaard, A.; Larsen, S. A branched N-linked glycan at atomic resolution in the 1.12 A structure of rhamnogalacturonan acetylesterase. Acta Crystallogr. D Biol. Crystallogr. 2002, 58, 111-119. [CrossRef] [PubMed]

77. Yoon, H.J.; Mikami, B.; Hashimoto, W.; Murata, K. Crystal structure of alginate lyase A1-III from Sphingomonas species A1 at 1.78 A resolution. J. Mol. Biol. 1999, 290, 505-514. [CrossRef] [PubMed]

78. Franklin, M.J.; Ohman, D.E. Mutant analysis and cellular localization of the AlgI, AlgJ, and AlgF proteins required for O acetylation of alginate in Pseudomonas aeruginosa. J. Bacteriol. 2002, 184, 3000-3007. [CrossRef] [PubMed]

79. Pelissier, M.C.; Lesley, S.A.; Kuhn, P.; Bourne, Y. Structural insights into the catalytic mechanism of bacterial guanosinediphosphoD-mannose pyrophosphorylase and its regulation by divalent ions. J. Biol. Chem. 2010, 285, 27468-27476. [CrossRef] [PubMed]

80. Urch, J.E.; Hurtado-Guerrero, R.; Brosson, D.; Liu, Z.; Eijsink, V.G.; Texier, C.; Van Aalten, D.M. Structural and functional characterization of a putative polysaccharide deacetylase of the human parasite Encephalitozoon cuniculi. Protein Sci. 2009, 18, 1197-1209. [CrossRef]

81. Zhang, Z.; Kulkarni, K.; Hanrahan, S.J.; Thompson, A.J.; Barford, D. The APC/C subunit Cdc16/Cut9 is a contiguous tetratricopeptide repeat superhelix with a homo-dimer interface similar to Cdc27. EMBO J. 2010, 29, 3733-3744. [CrossRef]

82. Bonsor, D.A.; Grishkovskaya, I.; Dodson, E.J.; Kleanthous, C. Molecular mimicry enables competitive recruitment by a natively disordered protein. J. Am. Chem. Soc. 2007, 129, 4800-4807. [CrossRef]

83. Wang, H.; Robinson, H.; Ke, H. Conformation changes, N-terminal involvement, and cGMP signal relay in the phosphodiesterase5 GAF domain. J. Biol. Chem. 2010, 285, 38149-38156. [CrossRef]

84. Li, J.; Qian, X.; Hu, J.; Sha, B. Molecular chaperone Hsp70/Hsp90 prepares the mitochondrial outer membrane translocon receptor Tom71 for preprotein loading. J. Biol. Chem. 2009, 284, 23852-23859. [CrossRef]

85. Chua, T.K.; Bujnicki, J.M.; Tan, T.C.; Huynh, F.; Patel, B.K.; Sivaraman, J. The structure of sucrose phosphate synthase from Halothermothrix orenii reveals its mechanism of action and binding mode. Plant Cell 2008, 20, 1059-1072. [CrossRef]

86. He, X.; Szewczyk, P.; Karyakin, A.; Evin, M.; Hong, W.X.; Zhang, Q.; Chang, G. Structure of a cation-bound multidrug and toxic compound extrusion transporter. Nature 2010, 467, 991-994. [CrossRef] [PubMed]

87. Whitfield, C. Biosynthesis and assembly of capsular polysaccharides in Escherichia coli. Annu. Rev. Biochem. 2006, 75, 39-68. [CrossRef] [PubMed]

88. Dong, C.; Beis, K.; Nesper, J.; Brunkan- Lamontagne, A.L.; Clarke, B.R.; Whitfield, C.; Naismith, J.H. Wza the translocon for E. coli capsular polysaccharides defines a new class of membrane protein. Nature 2006, 444, 226-229. [CrossRef] [PubMed]

89. Bechet, E.; Gruszczyk, J.; Terreux, R.; Gueguen-Chaignon, V.; Vigouroux, A.; Obadia, B.; Cozzone, A.J.; Nessler, S.; Grangeasse, C. Identification of structural and molecular determinants of the tyrosine-kinase Wzc and implications in capsular polysaccharide export. Mol. Microbiol. 2010, 77, 1315-1325. [CrossRef] [PubMed]

90. Guerin, M.E.; Kordulakova, J.; Schaeffer, F.; Svetlikova, Z.; Buschiazzo, A.; Giganti, D.; Gicquel, B.; Mikusova, K.; Jackson, M.; Alzari, P.M. Molecular recognition and interfacial catalysis by the essential phosphatidylinositol mannosyl transferase PimA from mycobacteria. J. Biol. Chem. 2007, 282, 20705-20714. [CrossRef]

91. Yang, J.K.; Yoon, H.J.; Ahn, H.J.; Lee, B.I.; Pedelacq, J.D.; Liong, E.C.; Berendzen, J.; Laivenieks, M.; Vieille, C.; Zeikus, G.J.; et al. Crystal structure of beta-Dxylosidase from Thermoanaerobacterium saccharolyticum, a family 39 glycoside hydrolase. J. Mol. Biol. 2004, 335, 155-165. [CrossRef] 
92. Favre-Bonté, S.; Chamot, E.; Köhler, T.; Romand, J.; van Delden, C. Auto inducer production and quorum-sensing dependent phenotypes of Pseudomonas aeruginosa vary according to isolation site during colonization of incubated patients. BMC Microbiol. 2007, 7, 33. [CrossRef]

93. Serralta, V.W.; Harison-Balestra, C.; Cazzaniga, A.L.; Davis, S.C.; Mertz, P.M. Lifestyles of bacteria in wounds: Presence of biofilms? Wounds 2001, 13, 29-34.

94. Nadell, C.D.; Xavier, J.B.; Levin, S.A.; Foster, K.R. The evolution of quorum sensing in bacterial biofilms. PLoS Biol. 2008,6 , e14. [CrossRef]

95. Dickschat, J.S. Quorum sensing and bacterial biofilms. Nat. Prod. Rep. 2010, 27, 343-369. [CrossRef] [PubMed]

96. Juhas, M.; Eberl, L.; Tümmler, B. Quorum sensing: The power of cooperation in the world of Pseudomonas. Environ. Microbiol. 2005, 7, 459-471. [CrossRef]

97. Hoang, T.T.; Sullivan, S.A.; Cusick, J.K.; Scihweizer, H.P. Beta-ketoacyl acyl carrier protein reductase (FabG) activity of the fatty acid biosynthetic pathway is a determining factor of 3-oxo-homoserine lactone acyl chain lengths. Microbiology 2002, 148, 3849-3856. [CrossRef] [PubMed]

98. Swift, S.; Karlyshev, A.V.; Fish, L.; Durant, E.L.; Winson, M.K.; Chhabra, S.R.; Williams, P.; Macintyre, S.; Stewart, G.S. Quorum sensing in Aeromonas hydrophila and Aeromonas salmonicida: Identification of the LuxRI homologs AhyRI and AsaRI and their cognate N-acylhomoserine lactone signal molecules. J. Bacteriol. 1997, 179, 5271-5281. [CrossRef] [PubMed]

99. Zhu, J.; Winans, S.C. The quorum-sensing transcriptional regulator TraR requires its cognate signaling ligand for protein folding, protease resistance, and dimerization. Proc. Natl. Acad. Sci. USA 2001, 98, 1507-1512. [CrossRef] [PubMed]

100. Welch, M.; Todd, D.E.; Whitehead, N.A.; McGowan, S.J.; Bycroft, B.W.; Salmond, G.P. N-acyl homoserine lactone binding to the CarR receptor determines quorum-sensing specificity in Erwinia. EMBO J. 2000, 19, 631-641. [CrossRef]

101. Hannan, S.; Ready, D.; Jasni, A.S.; Rogers, M.; Pratten, J.; Roberts, A.P. Transfer of antibiotic resistance by transformation with eDNA within oral biofilms. FEMS Immunol. Med. Microbiol. 2010, 59, 345-349. [CrossRef]

102. Klein, T.; Henn, C.; de Jong, J.C.; Zimmer, C.; Kirsch, B.; Maurer, C.K.; Pistorius, D.; Müller, R.; Steinbach, A.; Hartmann, R.W. Identification of small-molecule antagonists of the Pseudomonas aeruginosa transcriptional regulator PqsR: Biophysically guided hit discovery and optimization. ACS Chem. Biol. 2012, 7, 1496-1501. [CrossRef]

103. Storz, M.P.; Maurer, C.K.; Zimmer, C.; Wagner, N.; Brengel, C.; de Jong, J.C.; Lucas, S.; Müsken, M.; Häussler, S.; Steinbach, A.; et al. Validation of PqsD as an anti-biofilm target in Pseudomonas aeruginosa by development of small-molecule inhibitors. J. Am. Chem. Soc. 2012, 134, 16143-16146. [CrossRef]

104. Abraham, W. Going beyond the control of quorum-sensing to combat biofilm infections. Antibiotics 2016, 5, 3. [CrossRef]

105. Scutera, S.; Zucca, M.; Savoia, D. Novel approaches for the design and discovery of quorum-sensing inhibitors. Expert Opin. Drug Discov. 2014, 9, 353-366. [CrossRef]

106. Pearson, J.P.; Pesci, E.C.; Iglewski, B.H. Roles of Pseudomonas aeruginosa las and rhl quorum-sensing systems in control of elastase and rhamnolipid biosynthesis genes. J. Bacteriol. 1997, 179, 5756-5767. [CrossRef]

107. Davies, D.G.; Parsek, M.R.; Pearson, J.P.; Iglewski, B.H.; Costerton, J.W.; Greenberg, E.P. The involvement of cell-to-cell signals in the development of a bacterial biofilm. Science 1998, 280, 295-298. [CrossRef]

108. Lee, K.; Yoon, S.S. Pseudomonas aeruginosa biofilm, a programmed bacterial life for fitness. J. Microbiol. Biotechnol. 2017, 27, 1053-1064. [CrossRef]

109. Schuster, M.; Greenberg, E.P. A network of networks: Quorum-sensing gene regulation in Pseudomonas aeruginosa. Int. J. Med. Microbiol. 2006, 296, 73-81. [CrossRef] [PubMed]

110. Ni, N.; Li, M.; Wang, J.; Wang, B. Inhibitors and antagonists of bacterial quorum sensing. Med. Res. Rev. 2009, $29,65-124$. [CrossRef] [PubMed]

111. Bottomley, M.J.; Muraglia, E.; Bazzo, R.; Carfi, A. Molecular insights into quorum sensing in the human pathogen Pseudomonas aeruginosa from the structure of the virulence regulator LasR bound to its autoinducer. J. Biol. Chem. 2007, 282, 13592-13600. [CrossRef] [PubMed]

112. Schuster, M.; Urbanowski, M.L.; Greenberg, E.P. Promoter specificity in Pseudomonas aeruginosa quorum sensing revealed by DNA binding of purified LasR. Proc. Natl. Acad. Sci. USA 2004, 101, 15833-15839. [CrossRef]

113. Gilbert, K.B.; Kim, T.H.; Gupta, R.; Greenberg, E.P.; Schuster, M. Global position analysis of the Pseudomonas aeruginosa quorumsensing transcription factor LasR. Mol. Microbiol. 2009, 73, 1072-1085. [CrossRef]

114. Drees, S.L.; Fetzner, S. PqsE of Pseudomonas aeruginosa acts as pathway-specific thioesterase in the biosynthesis of alkylquinolone signaling molecules. Chem. Biol. 2015, 22, 611-618. [CrossRef]

115. O'Loughlin, C.T.; Miller, L.C.; Siryaporn, A.; Drescher, K.; Semmelhack, M.F.; Bassler, B.L. A quorum sensing inhibitor blocks Pseudomonas aeruginosa virulence and biofilm formation. Proc. Natl. Acad. Sci. USA 2013, 110, 17981-17986. [CrossRef] [PubMed]

116. Boursier, M.E.; Moore, J.D.; Heitman, K.M.; Shepardson-Fungairino, S.P.; Combs, J.B.; Koenig, L.C.; Shin, D.; Brown, E.C.; Nagarajan, R.; Blackwell, H.E. Structure-function analyses of the N-butanoyl l-homoserine lactone quorum sensing signal define features critical to activity in RhlR. ACS Chem. Biol. 2018, 13, 2655-2662. [CrossRef]

117. Yang, L.; Nilsson, M.; Gjermansen, M.; Givskov, M.; Tolker-Nielsen, T. Pyoverdine and PQS mediated subpopulation interactions involved in Pseudomonas aeruginosa biofilm formation. Mol. Microbiol. 2009, 74, 1380-1392. [CrossRef]

118. Pamp, S.J.; Tolker-Nielsen, T. Multiple roles of biosurfactants in structural biofilm development by Pseudomonas aeruginosa. J. Bacteriol. 2007, 189, 2531-2539. [CrossRef] 
119. Lee, J.; Zhang, L. The hierarchy quorum sensing network in Pseudomonas aeruginosa. Protein Cell 2015, 6, 26-41. [CrossRef] [PubMed]

120. Senturk, S.; Ulusoy, S.; Bosgelmez-Tinaz, G.; Yagci, A. Quorum sensing and virulence of Pseudomonas aeruginosa during urinary tract infections. J. Infect. Dev. Ctries 2012, 6, 501-507. [CrossRef] [PubMed]

121. Déziel, E.; Gopalan, S.; Tampakaki, A.P.; Lépine, F.; Padfield, K.E.; Saucier, M.; Xiao, G.; Rahme, L.G. The contribution of MvfR to Pseudomonas aeruginosa pathogenesis and quorum sensing circuitry regulation: Multiple quorum-sensing-regulated genes are modulated without affecting lasRI, rhlRI or the production of N-acyl-L-homoserine lactones. Mol. Microbiol. 2005, 55, 998-1014. [CrossRef] [PubMed]

122. Lau, G.W.; Ran, H.; Kong, F.; Hassett, D.J.; Mavrodi, D. Pseudomonas aeruginosa pyocyanin is critical for lung infection in mice. Infect. Immun. 2004, 72, 4275-4278. [CrossRef]

123. Collier, D.N.; Anderson, L.; McKnight, S.L.; Noah, T.L.; Knowles, M.; Boucher, R.; Schwab, U.; Gilligan, P.; Pesci, E.C. A bacterial cell to cell signal in the lungs of cystic fibrosis patients. FEMS Microbiol. Lett. 2002, 215, 41-46. [CrossRef] [PubMed]

124. Gallagher, L.A.; McKnight, S.L.; Kuznetsova, M.S.; Pesci, E.C.; Manoil, C. Functions required for extracellular quinolone signaling by Pseudomonas aeruginosa. J. Bacteriol. 2002, 184, 6472-6480. [CrossRef] [PubMed]

125. Lee, J.; Wu, J.; Deng, Y.; Wang, J.; Wang, C.; Wang, J.; Chang, C.; Dong, Y.; Williams, P.; Zhang, L. A cell-cell communication signal integrates quorum sensing and stress response. Nat. Chem. Biol. 2013, 9, 339-343. [CrossRef] [PubMed]

126. Dekimpe, V.; Déziel, E. Revisiting the quorum-sensing hierarchy in Pseudomonas aeruginosa: The transcriptional regulator RhlR regulates LasR-specific factors. Microbiology 2009, 155, 712-723. [CrossRef] [PubMed]

127. Jensen, V.; Lons, D.; Zaoui, C.; Bredenbruch, F.; Meissner, A.; Dieterich, G.; Munch, R.; Haussler, S. RhlR expression in Pseudomonas aeruginosa is modulated by the Pseudomonas quinolone signal via PhoB-dependent and -independent pathways. J. Bacteriol. 2006, 188, 8601-8606. [CrossRef]

128. Schafhauser, J.; Lepine, F.; McKay, G.; Ahlgren, H.G.; Khakimova, M.; Nguyen, D. The stringent response modulates 4-hydroxy2-alkylquinoline biosynthesis and quorum-sensing hierarchy in Pseudomonas aeruginosa. J. Bacteriol. 2014, 196, 1641-1650. [CrossRef]

129. Oglesby, A.G.; Farrow, J.M., 3rd; Lee, J.; Tomaras, A.P.; Greenberg, E.P.; Pesci, E.C.; Vasil, M.L. The influence of iron on Pseudomonas aeruginosa physiology: A regulatory link between iron and quorum sensing. J. Biol. Chem. 2008, 283, 15558-15567. [CrossRef]

130. Mattmann, M.E.; Shipway, P.M.; Heth, N.J.; Blackwell, H.E. Potent and selective synthetic modulators of a quorum sensing repressor in Pseudomonas aeruginosa identified from second-generation libraries of N-acylated L-homoserine lactones. Chem Biochem. 2011, 12, 942-949. [CrossRef]

131. Patankar, A.V.; González, J.E. Orphan LuxR regulators of quorum sensing. FEMS Microbiol. Rev. 2009, 33, 739-756. [CrossRef]

132. Parkins, M.D.; Ceri, H.; Storey, D.G. Pseudomonas aeruginosa GacA, a factor in multihost virulence, is also essential for biofilm formation. Mol. Microbiol. 2001, 40, 1215-1226. [CrossRef]

133. Rodrigue, A.; Quentin, Y.; Lazdunski, A.; Méjean, V.; Foglino, M. Two-component systems in Pseudomonas aeruginosa: Why so many? Trends Microbiol. 2000, 8, 498-504. [CrossRef]

134. Shrout, J.D.; Chopp, D.L.; Just, C.L.; Hentzer, M.; Givskov, M.; Parsek, M.R. The impact of quorum sensing and swarming motility on Pseudomonas aeruginosa biofilm formation is nutritionally conditional. Mol. Microbiol. 2006, 62, 1264-1277. [CrossRef]

135. Daniels, R.; Vanderleyden, J.; Michiels, J. Quorum sensing and swarming migration in bacteria. FEMS Microbiol. Rev. 2004, 28, 261-289. [CrossRef]

136. Patriquin, G.M.; Banin, E.; Gilmour, C.; Tuchman, R.; Greenberg, E.P.; Poole, K. Influence of quorum sensing and iron on twitching motility and biofilm formation in Pseudomonas aeruginosa. J. Bacteriol. 2008, 190, 662-671. [CrossRef]

137. Mattick, J.S. Type IV pili and twitching motility. Annu. Rev. Microbiol. 2002, 56, 289-314. [CrossRef]

138. Dusane, D.H.; Zinjarde, S.S.; Venugopalan, V.P.; Mclean, R.J.C.; Weber, M.M.; Rahman, P.K.S.M. Quorum sensing: Implications on Rhamnolipid biosurfactant production. Biotechnol. Genet. Eng. Rev. 2010, 27, 159-184. [CrossRef]

139. Boles, B.R.; Thoendel, M.; Singh, P.K. Rhamnolipids mediate detachment of Pseudomonas aeruginosa from biofilms. Mol. Microbiol. 2005, 57, 1210-1223. [CrossRef] [PubMed]

140. Diggle, S.P.; Stacey, R.E.; Dodd, C.; Cámara, M.; Williams, P.; Winzer, K. The galactophilic lectin, LecA, contributes to biofilm development in Pseudomonas aeruginosa. Environ. Microbiol. 2006, 8, 1095-1104. [CrossRef] [PubMed]

141. Tielker, D.; Hacker, S.; Loris, R.; Strathmann, M.; Wingender, J.; Wilhelm, S.; Rosenau, F.; Jaeger, K. Pseudomonas aeruginosa lectin LecB is located in the outer membrane and is involved in biofilm formation. Microbiology 2005, 151, 1313-1323. [CrossRef] [PubMed]

142. Høiby, N.; Ciofu, O.; Johansen, H.K.; Song, Z.; Moser, C.; Jensen, P.Ø.; Molin, S.; Givskov, M.; Tolker-Nielsen, T.; Bjarnsholt, T. The clinical impact of bacterial biofilms. Int. J. Oral Sci. 2011, 3, 55-65. [CrossRef]

143. Mah, T.F.; O'Toole, G.A. Mechanisms of biofilm resistance to antimicrobial agents. Trends Microbiol. 2001, 9, 34-39. [CrossRef]

144. Xu, K.D.; McFeters, G.A.; Stewart, P.S. Biofilm resistance to antimicrobial agents. Microbiology 2000, 146, 547-549. [CrossRef] [PubMed]

145. Cochran, W.L.; McFeters, G.A.; Stewart, P.S. Reduced susceptibility of thin Pseudomonas aeruginosa biofilms to hydrogen peroxide and monochloramine. J. Appl. Microbiol. 2000, 88, 22-30. [CrossRef] [PubMed]

146. Kragh, K.N.; Hutchison, J.B.; Melaugh, G.; Rodesney, C.; Roberts, A.E.L.; Irie, Y.; Jensen, P.Ø.; Diggle, S.P.; Allen, R.J.; Gordon, V.; et al. Role of multicellular aggregates in biofilm formation. mBio 2016, 7, e00237-16. [CrossRef] 
147. Sugimoto, S.; Okuda, K.; Miyakawa, R.; Sato, M.; Arita-Morioka, K.; Chiba, A.; Yamanaka, K.; Ogura, T.; Mizunoe, Y.; Sato, C. Imaging of bacterial multicellular behaviour in biofilms in liquid by atmospheric scanning electron microscopy. Sci. Rep. 2016, 6, 25889. [CrossRef] [PubMed]

148. Lister, P.D.; Wolter, D.J.; Hanson, N.D. Antibacterial-resistant Pseudomonas aeruginosa: Clinical impact and complex regulation of chromosomally encoded resistance mechanisms. Clin. Microbiol. Rev. 2009, 22, 582-610. [CrossRef]

149. Tacconelli, E.; Carrara, E.; Savoldi, A.; Harbarth, S.; Mendelson, M.; Monnet, D.L.; Pulcini, C.; Kahlmeter, G.; Kluytmans, J.; Carmeli, Y.; et al. WHO Pathogens Priority List Working Group. Discovery, research, and development of new antibiotics: The WHO priority list of antibiotic resistant bacteria and tuberculosis. Lancet Infect. Dis. 2018, 18, 318-327. [CrossRef]

150. Park, S.Y.; Park, H.J.; Moon, S.M.; Park, K.H.; Chong, Y.P.; Kim, M.N.; Kim, S.H.; Lee, S.O.; Kim, Y.S.; Woo, J.H.; et al. Impact of adequate empirical combination therapy on mortality from bacteremic Pseudomonas aeruginosa pneumonia. BMC Infect. Dis. 2012, 12, 308. [CrossRef]

151. Hirsch, E.B.; Tam, V.H. Impact of multidrug-resistant Pseudomonas aeruginosa infection on patient outcomes. Expert Rev. Pharm. Outcomes Res. 2010, 10, 441-451. [CrossRef]

152. El Solh, A.A.; Alhajhusain, A. Update on the treatment of Pseudomonas aeruginosa pneumonia. J. Antimicrob. Chemother. 2009, 64, 229-238. [CrossRef]

153. Hancock, R.E.W.; Speert, D.P. Antibiotic resistance in Pseudomonas aeruginosa: Mechanisms and impact on treatment. Drug Resist. Updat. 2000, 3, 247-255. [CrossRef]

154. Breidenstein, E.B.M.; de la Fuente-Núñez, C.; Hancock, R.E.W. Pseudomonas aeruginosa: All roads lead to resistance. Trends Microbiol. 2011, 19, 419-426. [CrossRef]

155. Mulcahy, L.R.; Burns, J.L.; Lory, S.; Lewis, K. Emergence of Pseudomonas aeruginosa strains producing high levels of persister cells in patients with cystic fibrosis. J. Bacteriol. 2010, 192, 6191-6199. [CrossRef]

156. Ayrapetyan, M.; Williams, T.C.; Oliver, J.D. Bridging the gap between viable but non-culturable and antibiotic persistent bacteria. Trends Microbiol. 2015, 23, 7-13. [CrossRef]

157. Helaine, S.; Kugelberg, E. Bacterial persisters: Formation, eradication, and experimental systems. Trends Microbiol. 2014, 22, 417-424. [CrossRef]

158. Mlynarcik, P.; Kolar, M. Starvation- and antibiotics-induced formation of persister cells in Pseudomonas aeruginosa. Biomed. Pap. Med. Fac. Univ. Palacky Olomouc. Czech Repub. 2017, 161, 58-67. [CrossRef]

159. Keren, I.; Minami, S.; Rubin, E.; Lewis, K. Characterization and transcriptome analysis of Mycobacterium tuberculosis persisters. mBio 2011, 2, e00100-11. [CrossRef] [PubMed]

160. Amato, S.M.; Fazen, C.H.; Henry, T.C.; Mok, W.W.K.; Orman, M.A.; Sandvik, E.L.; Volzing, K.G.; Brynildsen, M.P. The role of metabolism in bacterial persistence. Front. Microbiol. 2014, 5, 70. [CrossRef] [PubMed]

161. Singh, P.K.; Schaefer, A.L.; Parsek, M.R.; Moninger, T.O.; Welsh, M.J.; Greenberg, E.P. Quorum-sensing signals indicate that cystic fibrosis lungs are infected with bacterial biofilms. Nature 2000, 407, 762-764. [CrossRef] [PubMed]

162. Kaur, G.; Balamurugan, P.; Vasudevan, S.; Jadav, S.; Princy, S.A. Antimicrobial and antibiofilm potential of acyclic amines and diamines against multi-drug resistant Staphylococcus aureus. Front. Microbiol. 2017, 8, 1767. [CrossRef] [PubMed]

163. Flemming, H.; Wingender, J.; Szewzyk, U.; Steinberg, P.; Rice, S.A.; Kjelleberg, S. Biofilms: An emergent form of bacterial life. Nat. Rev. Microbiol. 2016, 14, 563-575. [CrossRef]

164. Sharma, D.; Misba, L.; Khan, A.U. Antibiotics versus biofilms: An emerging battleground in microbial communities. Anitimicrob. Resist. Infect. Control. 2019, 8, 76. [CrossRef] [PubMed]

165. Algburi, A.; Comito, N.; Kashtanov, D.; Dicks, L.M.T.; Chikindas, M.L. Control of biofilm formation: Antibiotics and Beyond. Appl. Environ. Microbiol. 2017, 83, e02508-16. [CrossRef] [PubMed]

166. Bernardes, E.V.T.; Lewenza, S.; Zenteno, S.R. Current research approaches to target biofilm infections. Postdoc. J. 2015, 3, 36-49. [CrossRef] [PubMed]

167. Lu, L.; Hu, W.; Tian, Z.; Yuan, D.; Yi, G.; Zhou, Y.; Cheng, Q.; Zhu, J.; Li, M. Developing natural products as potential anti-biofilm agents. Chin. Med. 2019, 14, 11. [CrossRef]

168. Al-Haidari, R.A.; Shaaban, M.I.; Ibrahim, S.R.M.; Mohamed, G.A. Anti-quorum sensing activity of some medicinal plants. Afr. J. Tradit. Complement Altern. Med. 2016, 13, 67-71. [PubMed]

169. Musthafa, K.S.; Ravi, A.V.; Annapoorani, A.; Packiavathy, I.S.V.; Pandian, S.K. Evaluation of anti-quorum-sensing activity of edible plants and fruits through inhibition of the $\mathrm{N}$-acyl-homoserine lactone system in Chromobacterium violaceum and Pseudomonas aeruginosa. Chemotherapy 2010, 56, 333-339. [CrossRef]

170. Vasavi, H.S.; Arun, A.B.; Rekha, P.D. Anti-quorum sensing activity of flavonoid rich fraction from Centella asiatica L. against Pseudomonas aeruginosa PAO1. J. Microbiol. Immunol. Infect. 2016, 49, 8-15. [CrossRef] [PubMed]

171. Al-Dhabi, N.A.; Balachandran, C.; Raj, M.K.; Duraipandiyan, V.; Muthukumar, C.; Ignacimuthu, S.; Khan, I.A.; Rajput, V.S. Antimicrobial, antimycobacterial and antibiofilm properties of Couroupita guianensis Aubl. fruit extract. BMC Complement. Altern. Med. 2012, 12, 242. [CrossRef]

172. Perumal, S.; Mahmud, R. Chemical analysis, inhibition of biofilm formation and biofilm eradication potential of Euphorbia hirta L. against clinical isolates and standard strains. BMC Complement. Altern. Med. 2013, 13, 346. [CrossRef] 
173. Bjarnsholt, T.; Jensen, P.Ø.; Rasmussen, T.B.; Christophersen, L.; Calum, H.; Hentzer, M.; Hougen, H.P.; Rygaard, J.; Moser, C.; Eberl, L.; et al. Garlic blocks quorum sensing and promotes rapid clearing of pulmonary Pseudomonas aeruginosa infections. Microbiology 2005, 151, 3873-3880. [CrossRef]

174. Zahin, M.; Hasan, S.; Aqil, K.; Khan, M.S.A.; Husain, F.M.; Ahmad, I. Screening of certain medicinal plants from India for their anti-quorum sensing activity. Indian J. Exp. Biol. 2010, 48, 1219-1224.

175. Song, Z.; Kong, K.F.; Wu, H.; Maricic, N.; Ramalingam, B.; Priestap, H.; Schneper, L.; Quirke, J.M.E.; Høiby, N.; Mathee, K. Panax ginseng has anti-infective activity against opportunistic pathogen Pseudomonas aeruginosa by inhibiting quorum sensing, a bacterial communication process critical for establishing infection. Phytomedicine 2010, 17, 1040-1046. [CrossRef] [PubMed]

176. Silva, M.S.P.; Brandão, D.O.; Chaves, T.P.; Filho, A.L.N.F.; de B Costa, E.M.M.; Santos, V.L.; Medeiros, A.C.D. Study bioprospecting of medicinal plant extracts of the semiarid northeast: Contribution to the control of oral microorganisms. Evid. Based Complement. Alternat. Med. 2012, 2, 681207. [CrossRef] [PubMed]

177. Krishnan, T.; Yin, W.F.; Chan, K.G. Inhibition of quorum sensing-controlled virulence factor production in Pseudomonas aeruginosa PA01 by ayurveda spice clove (Syzygium aromaticum) bud extract. Sensors 2012, 12, 4016-4030. [CrossRef]

178. Taganna, J.C.; Quanico, J.P.; Perono, R.M.G.; Amor, E.C.; Rivera, W. Tannin-rich fraction from Terminalia catappa inhibits quorum sensing (QS) in Chromobacterium violaceum and the QS-controlled biofilms maturation and LasA staphylolytic activity in Pseudomonas aeruginosa. J. Ethnopharmacol. 2011, 134, 865-871. [CrossRef] [PubMed]

179. Juarez, I.C.; Contreras, R.G.; Guadarrama, N.V.; Hernandez, M.S.; Vazquez, M.M. Amphypterygium adstringens anacardic acid mixture inhibits quorum sensing controlled virulence factors of Chromobacterium violaceum and Pseudomonas aeruginosa. Arch. Med. Res. 2013, 44, 488-494. [CrossRef]

180. Sarkar, R.; Chaudhary, S.K.; Sharma, A.; Yadav, K.; Nema, N.; Sekhoacha, M.; Karmakar, S.; Braga, F.C.; Matsabisa, M.G.; Mukherjee, P.K.; et al. Anti-biofilm activity of Marula- a study with the standardized bark extract. J. Ethnopharmacol. 2014, 154, 170-175. [CrossRef]

181. Vattem, D.A.; Mihalik, K.; Crixell, S.H.; McLean, R.J.C. Dietary phytochemicals as quorum sensing inhibitors. J. Fitoterapia 2007, 78, 302-310. [CrossRef]

182. Chong, Y.M.; Yin, W.F.; Ho, C.Y.; Mustafa, M.R.; Hamid, A.; Hadi, A.; Awang, K.; Narrima, P.; Koh, C.L.; Appleton, D.R.; et al. Malabaricone C from Myristica cinnamomea exhibits anti-quorum sensing activity. J. Nat. Prod. 2011, 74, 2261-2264. [CrossRef]

183. Tan, L.Y.; Yin, W.F.; Chan, K.G. Silencing quorum sensing through extracts of Melicope lunu-ankenda. Sensors 2012, 12, 4339-4351. [CrossRef]

184. Priya, K.; Yin, W.F.; Chan, K.G. Anti-quorum sensing activity of the traditional Chinese herb, Phyllanthus amarus. Sensors 2013, 13, 14558-14569. [CrossRef] [PubMed]

185. Abraham, S.V.P.I.; Palani, A.; Ramaswamy, B.R.; Shunmugiah, K.P.; Arumugam, V.R. Antiquorum sensing and antibiofilm potential of Capparis spinosa. J. Arch. Med. Res. 2011, 42, 658-668. [CrossRef] [PubMed]

186. Hossain, M.A.; Lee, S.J.; Park, J.Y.; Reza, M.A.; Kim, T.H.; Lee, K.J.; Suh, J.W.; Park, S.C. Modulation of quorum sensing-controlled virulence factors by Nymphaea tetragona (waterlily) extract. J. Ethnopharmcol. 2015, 174, 482-491. [CrossRef] [PubMed]

187. Shukla, V.; Bhathena, Z. Broad spectrum anti-quorum sensing activity of tannin-rich crude extracts of Indian medicinal plants. Scientifica 2016, 5, 5823013. [CrossRef]

188. Mombeshora, M.; Chi, G.F.; Mukanganyama, S. Antibiofilm activity of extract and a compound isolated from Triumfetta welwitschii against Pseudomonas aeruginosa. Biochem. Res. Int. 2021, 14, 9946183.

189. Al-Youef, H.M.; Alam, P.; Khanam, Z.; Amnia, M.; Hassan, W.H.B. Corchorus olitorius aqueous extract attenuates quorum-sensing regulated virulence factor production and biofilm formation. Asian Pac. J. Trop. Biomed. 2021, 11, 66-73. [CrossRef]

190. Jalli, N.; Sri, K.V.S.; Hnamte, S.; Pattnaik, S.; Paramanantham, P.; Siddhardha, B. Antioxidant, anti-quorum sensing and anti-biofilm potential of ethanolic leaf extract of Phrylium capitatum and Dryptes indica. Asian Pac. J. Biomed. 2019, 9, $323-332$.

191. Li, S.; Yao, J.; Li, H. Plantain Herb Extracts significantly attenuate the quorum sensing-controlled virulence factors and inhibit biofilm formation in Pseudomonas aeruginosa PAO1. E3S Web Conf. 2019, 78, 01004. [CrossRef]

192. Topa, S.H.; Palombo, E.A.; Kingshott, P.; Blackall, L.L. Activity of Cinnamaldehyde on quorum sensing and biofilm susceptibility to antibiotics in Pseudomonas aeruginosa. Microorganisms 2020, 8, 455. [CrossRef]

193. Hnamte, S.; Subhaswaraj, P.; Ranganathan, S.K.; Ampasala, D.R.; Muralitharan, G.; Siddhardha, B. Antiquorum sensing and antibiofilm potential of Anogeissus acuminata and Mallotus roxburghianus Muell. against Pseudomonas aeruginosa PAO1. J. Microbiol. Biotechnol. Food Sci. 2019, 8, 1135-1140.

194. Jalli, N.; Sri, K.V.S.; Hnamte, S.; Pattnaik, S.; Paramanantham, P.; Siddhardha, B. Experimental investigations on Camellia kissi wall. for antioxidant, anti-quorum sensing and anti-biofilm activities. J. Microbiol. Biotechnol. Food Sci. 2020, 9, 736-741. [CrossRef]

195. Hnamte, S.; Subhaswaraj, P.; Ranganathan, S.K.; Ampasala, D.R.; Muralitharan, G.; Siddhardha, B. Methanolic extract of Plectranthus tenuiflorus attenuates quorum sensing mediated virulence and biofilm formation in Pseudomonas aeruginosa PAO1. J. Pure Appl. Microbiol. 2018, 12, 1985-1996. [CrossRef]

196. Jovanović, M.; Morić, I.; Nikolić, B.; Pavić, A.; Svirčev, E.; Šenerović, L.; Mitić-Ćulafić, D. Anti-virulence potential and in vivo toxicity of Persicaria maculosa and Bistorta officinalis extracts. Molecules 2020, 25, 1811. [CrossRef]

197. Famuyide, I.M.; Aro, A.O.; Fasina, F.O.; Eloff, J.N.; McGaw, L.J. Antibacterial and antibiofilm activity of acetone leaf extracts of nine under-investigated south African Eugenia and Syzygium (Myrtaceae) species and their selectivity indices. BMC Complement Altern. Med. 2019, 19, 141. [CrossRef] [PubMed] 
198. Alam, K.; Farraj, D.A.A.; Mah-e-Fatima, S.; Yameen, M.A.; Elshikh, M.S.; Alkufeidy, R.M.; Naqvi, T.A. Anti-biofilm activity of plant derived extracts against infectious pathogen-Pseudomonas aeruginosa PAO1. J. Infect. Public Health 2020, 13, $1734-1741$. [CrossRef] [PubMed]

199. Emam, M.; Abdel-Haleem, D.R.; Salem, M.M.; Abdel-Hafez, L.J.M.; Latif, R.R.A.; Farag, S.M.; El Raey, M.A. Phytochemical profiling of Lavandula coronopifolia Poir. aerial parts extract and its larvicidal, antibacterial, and antibiofilm activity against Pseudomonas aeruginosa. Molecules 2021, 26, 1710. [PubMed]

200. Jahan, M.; Abuhena, M.D.; Azad, A.K.; Karim, M.M. In vitro antibacterial and antibiofilm activity of selected medicinal plants and spices extracts against multidrug resistant Pseudomonas aeruginosa. J. Pharmacogn. Phytochem. 2018, 7, $2114-2121$.

201. Torres, C.E.; Lenon, G.; Craperi, D.; Wilting, R.; Blanco, A. Enzymatic treatment for preventing biofilm formation in the paper industry. Appl. Microbiol. Biotechnol. 2011, 92, 95-103. [CrossRef]

202. Kovach, K.N.; Fleming, D.; Wells, M.J.; Rumbaugh, K.P.; Gordon, V.D. Specific disruption of established P. aeruginosa biofilms using polymer-attacking enzymes. Langmuir 2020, 36, 1585-1595. [CrossRef]

203. Dong, Y.H.; Xu, J.L.; Li, X.Z.; Zhang, L.H. AiiA, an enzyme that inactivates the acylhomoserine lactone quorum-sensing signal and attenuates the virulence of Erwinia carotovora. Proc. Natl. Acad. Sci. USA 2000, 97, 3526-3531. [CrossRef]

204. Bräuer, N.W.; Kisch, M.J.; Pinnow, N.; Liese, A.; Schmitz, R.A. Highly effective inhibition of biofilm formation by the first metagenome-derived AI-2 quenching enzyme. Front. Microbiol. 2016, 7, 1098.

205. Fetzner, S. Quorum quenching enzymes. J. Biotechnol. 2015, 201, 2-14. [CrossRef] [PubMed]

206. Gawande, P.V.; Clinton, A.P.; Lovetri, K.; Yakandawala, N.; Rumbaugh, K.P.; Madhyastha, S. Antibiofilm efficacy of DispersinB®wound spray used in combination with a silver wound dressing. Microbiol. Insights 2014, 7, 9-13. [CrossRef] [PubMed]

207. Gawande, P.V.; Leung, K.P.; Madhyastha, S. Antibiofilm and antimicrobial efficacy of DispersinB ${ }^{\circledR}$-KSL-W peptide-based wound gel against chronic wound infection associated bacteria. Curr. Microbiol. 2014, 68, 635-641. [CrossRef] [PubMed]

208. Demidova-Rice, T.N.; Hamblin, M.R.; Herman, I.M. Acute and impaired wound healing: Pathophysiology and current methods for drug delivery, part 1: Normal and chronic wounds: Biology, causes, and approaches to care. Adv. Skin Wound Care 2012, 25, 304-314. [CrossRef]

209. Ramundo, J.; Gray, M. Enzymatic wound debridement. J. Wound Ostomy Cont. Nurs. 2008, 35, 273-280. [CrossRef]

210. Falabella, A.F. Debridement and wound bed preparation. Dermatol. Ther. 2006, 19, 317-325. [CrossRef]

211. Ge, L.; Zhao, Y.S.; Mo, T.; Li, J.R.; Li, P. Immobilization of glucose oxidase in electrospun nanofibrous membranes for food preservation. Food Control. 2012, 26, 188-193. [CrossRef]

212. Hansen, E.H.; Albertsen, L.; Schafer, T.; Johansen, C.; Frisvad, J.C.; Molin, S.; Gram, L. Curvularia haloperoxidase: Antimicrobial activity and potential application as a surface disinfectant. Appl. Environ. Microbiol. 2003, 69, 4611-4617. [CrossRef]

213. Barton, N.; Robertson, D.; Chang, K.; Elkins, J. Enzymes and the Nucleic Acids Encoding Them and Methods for Making and Using Them. WIPO Patent WO2004066945, 8 December 2004.

214. Fagerlund, A.; Langsrud, S.; Heir, E.; Mikkelsen, M.I.; Møretrø, T. Biofilm matrix composition affects the susceptibility of food associated staphylococci to cleaning and disinfection agents. Front. Microbiol. 2016, 7, 856. [CrossRef]

215. Kalpana, B.J.; Aarthy, S.; Pandian, S.K. Antibiofilm activity of $\alpha$-amylase from Bacillus subtilis S8-18 against biofilm forming human bacterial pathogens. Appl. Biochem. Biotechnol. 2012, 167, 1778-1794. [CrossRef]

216. Lamppa, J.W.; Griswold, K.E. Alginate lyase exhibits catalysis-independent biofilm dispersion and antibiotic synergy. Antimicrob. Agents Chemother. 2013, 57, 137-145. [CrossRef] [PubMed]

217. Grover, N.; Plaks, J.G.; Summers, S.R.; Chado, G.R.; Schurr, M.J.; Kaar, J.L. Acylase-containing polyurethane coatings with anti-biofilm activity. Biotechnol. Bioeng. 2016, 113, 2535-2543. [CrossRef] [PubMed]

218. Ivanova, K.; Fernandes, M.M.; Mendoza, E.; Tzanov, T. Enzyme multilayer coatings inhibit Pseudomonas aeruginosa biofilm formation on urinary catheters. Appl. Microbiol. Biotechnol. 2015, 99, 4373-4385. [CrossRef]

219. Vogel, J.; Havinga, M.W.; Setroikromo, R.; Quax, W.J. Immobilized acylase PvdQ reduces Pseudomonas aeruginosa biofilm formation on PDMS silicone. Front. Chem. 2020, 8, 1-9. [CrossRef]

220. Hukić, M.; Seljmo, D.; Ramovic, A.; Ibrišimović, M.A.; Dogan, S.; Hukic, J.; Bojic, E.F. The effect of lysozyme on reducing biofilms by Staphylococcus aureus, Pseudomonas aeruginosa, and Gardnerella vaginalis: An in vitro examination. Microb. Drug Resist. 2018, 24, 353-358. [CrossRef] [PubMed]

221. Sebaa, S.; Hizette, N.; Otmani, Z.B.; Courtois, P. Dose-dependent effect of lysozyme upon Candida albican biofilm. Mol. Med. Rep. 2017, 15, 1135-1142. [CrossRef]

222. Shukla, S.K.; Rao, T.S. Staphylococcus aureus biofilm removal by targeting biofilm-associated extracellular proteins. Indian J. Med. Res. 2017, 146, S1-S8.

223. Eladawy, M.; Mowafy, M.E.; Sokkary, M.E.; Barwa, R. Effects of lysozyme, proteinase K, and cephalosporins on biofilm formation by clinical isolates of Pseudomonas aeruginosa. Interdiscip. Perspect. Infect. Dis. 2020, 4, 6156720. [CrossRef]

224. Bijtenhoorn, P.; Mayerhofer, H.; Dieckmann, J.M.; Utpatel, C.; Schipper, C.; Hornung, C.; Szesny, M.; Grond, S.; Thürmer, A.; Brzuszkiewicz, E.; et al. A novel metagenomic Short-Chain dehydrogenase/reductase attenuates Pseudomonas aeruginosa biofilm formation and virulence on Caenorhabditis elegans. PLoS ONE 2011, 6, e26278. [CrossRef] [PubMed]

225. Witzgall, F.; Depke, T.; Hoffmann, M.; Empting, M.; Brönstrup, M.; Müller, R.; Blankenfeldt, W. The alkylquinolone repertoire of Pseudomonas aeruginosa is linked to structural flexibility of the FabH-like 2-heptyl-3-hydroxy-4(1H)-quinolone (PQS) biosynthesis enzyme PqsBC. Chembiochem 2018, 19, 1531-1544. [CrossRef] [PubMed] 
226. Hodgkinson, J.T.; Galloway, W.R.; Welch, M.; Spring, D.R. Microwave-assisted preparation of the quorum sensing molecule 2-heptyl-3-hydroxy-4(1H)-quinolone and structurally related analogs. Nat. Protoc. 2012, 7, 1184-1192. [CrossRef] [PubMed]

227. Banar, M.; Emaneini, M.; Beigverdi, R.; Pirlar, R.F.; Farahani, N.N.; van Leeuwen, W.B.; Abalameli, F. The efficacy of lyticase and $\beta$-glucosidase enzymes on biofilm degradation of Pseudomonas aeruginosa strains with different gene profiles. BMC Microbiol. 2019, 19, 291. [CrossRef] [PubMed]

228. Daboor, S.M.; Raudonis, R.; Cohen, A.; Rohde, J.R.; Cheng, Z. Marine bacteria, a source for alginolytic enzyme to disrupt Pseudomonas aeruginosa biofilms. Mar. Drugs 2019, 17, 307. [CrossRef] [PubMed]

229. Mion, S.; Rémy, B.; Plener, L.; Brégeon, F.; Chabrière, E.; Daudé, D. Quorum quenching lactonase strengthens bacteriophage and antibiotic arsenal against Pseudomonas aeruginosa clinical isolates. Front. Microbiol. 2019, 10, 1-11. [CrossRef] [PubMed]

230. Snarr, B.D.; Baker, P.; Bamford, N.C.; Sato, Y.; Liu, H.; Lehoux, M.; Gravelat, F.N.; Ostapska, H.; Baistrocchi, S.R.; Cerone, R.P.; et al. Microbial glycoside hydrolases as antibiofilm agents with cross-kingdom activity. Proc. Natl. Acad. Sci. USA 2017, 114, 7124-7129. [CrossRef]

231. Stiefel, P.; Mauerhofer, S.; Schneider, J.; Weber, K.M.; Rosenberg, U.; Ren, Q. Enzymes enhance biofilm removal efficiency of cleaners. Antimicrob. Agents Chemother. 2016, 60, 3646-3652. [CrossRef]

232. Banar, M.; Emaneini, M.; Satarzadeh, M.; Abdellahi, N.; Beigverdi, R.; van Leeuwen, W.B.; Jabalameli, F. Evaluation of mannosidase and trypsin enzymes effects on biofilm production of Pseudomonas aeruginosa isolated from burn wound infections. PLoS ONE 2016, 11, e0164622. [CrossRef] [PubMed]

233. Hymes, S.R.; Randis, T.M.; Sun, T.Y.; Ratner, A.J. DNase inhibits Gardnerella vaginalis biofilms in vitro and in vivo. J. Infect. Dis. 2013, 207, 1491-1497. [CrossRef] [PubMed]

234. Tetz, G.V.; Artemenko, N.K.; Tetz, V.V. Effect of DNase and antibiotics on biofilm characteristics. Antimicrob. Agents Chemother. 2009, 53, 1204-1209. [CrossRef]

235. Parks, Q.M.; Young, R.L.; Poch, K.R.; Malcolm, K.C.; Vasil, M.L.; Nick, J.A. Neutrophil enhancement of Pseudomonas aeruginosa biofilm development: Human F-actin and DNA as targets for therapy. J. Med. Microbiol. 2009, 58, 492-502. [CrossRef]

236. Darouiche, R.O.; Mansouri, M.D.; Gawande, P.V.; Madhyastha, S. Antimicrobial and antibiofilm efficacy of triclosan and DispersinB ${ }^{\circledR}$ combination. J. Antimicrob. Chemother. 2009, 64, 88-93. [CrossRef] [PubMed]

237. Messiaen, A.S.; Nelis, H.; Coenye, T. Investigating the role of matrix components in protection of Burkholderia cepacia complex biofilms against tobramycin. J. Cyst. Fibros. 2014, 13, 56-62. [CrossRef] [PubMed]

238. Park, J.H.; Lee, J.H.; Cho, M.H.; Herzberg, M.; Lee, J. Acceleration of protease effect on Staphylococcus aureus biofilm dispersal. FEMS Microbiol. Lett. 2012, 335, 31-38. [CrossRef] [PubMed]

239. Nijland, R.; Hall, M.J.; Burgess, J.G. Dispersal of biofilms by secreted, matrix degrading, bacterial DNase. PLoS ONE 2010, 5, e15668. [CrossRef] [PubMed]

240. Baker, P.; Hill, P.J.; Snarr, B.D.; Alnabelseya, N.; Pestrak, M.J.; Lee, M.J.; Jennings, L.K.; Tam, J.; Melnyk, R.A.; Parsek, M.R.; et al. Exopolysaccharide biosynthetic glycoside hydrolases can be utilized to disrupt and prevent Pseudomonas aeruginosa biofilms. Sci. Adv. 2016, 2, e1501632. [CrossRef] [PubMed]

241. Kiran, S.; Sharma, P.; Harjai, K.; Capalash, N. Enzymatic quorum quenching increases antibiotic susceptibility of multidrug resistant Pseudomonas aeruginosa. Iran. J. Microbiol. 2011, 3, 1-12. [PubMed]

242. Tielen, P.; Rosenau, F.; Wilhelm, S.; Jaeger, K.E.; Flemming, H.C.; Wingender, J. Extracellular enzymes affect biofilm formation of mucoid Pseudomonas aeruginosa. Microbiology 2010, 156, 2239-2252. [CrossRef]

243. Kaplan, J.B. Therapeutic potential of biofilm-dispersing enzymes. Int. J. Artif. Organs 2009, 32, 545-554. [CrossRef]

244. Wang, M.; Zhao, L.; Wu, H.; Zhao, C.; Gong, Q.; Yu, W. Cladodionen is a potential quorum sensing inhibitor against Pseudomonas aeruginosa. Mar. Drugs 2020, 18, 205. [CrossRef]

245. Sadiq, S.; Rana, N.F.; Zahid, M.A.; Zargaham, M.K.; Tanweer, T.; Batool, A.; Naeem, A.; Nawaz, A.; Rizwan-ur-Rehman; Muneer, Z.; et al. Virtual screening of FDA-approved drugs against LasR of Pseudomonas aeruginosa for antibiofilm potential. Molecules 2020, 25, 3723. [CrossRef] [PubMed]

246. Baldelli, V.; D'Angelo, F.; Pavoncello, V.; Fiscarelli, E.V.; Visca, P.; Rampioni, G.; Leoni, L. Identification of FDA-approved antivirulence drugs targeting the Pseudomonas aeruginosa quorum sensing effector protein PqsE. Virulence 2020, 11, 652-668. [CrossRef]

247. Abelyan, N.; Grabski, H.; Tiratsuyan, S. In silico screening of flavones and its derivatives as potential inhibitors of quorum-sensing regulator LasR of Pseudomonas aeruginosa. J. Mol. Biol. 2020, 54, 153-163. [CrossRef]

248. Mellini, M.; Muzio, E.D.; D’Angelo, F.; Baldelli, V.; Ferrillo, S.; Visca, P.; Leoni, L.; Polticelli, F.; Rampioni, G. In silico selection and experimental validation of FDA approved drugs as anti-quorum sensing agents. Front. Microbiol. 2019, 10, 2355. [CrossRef] [PubMed]

249. Shah, M.D.; Kharkar, P.S.; Sahu, N.U.; Peerzada, Z.; Desai, K.B. Potassium 2-methoxy-4-vinylphenolate: A novel hit exhibiting quorum-sensing inhibition in Pseudomonas aeruginosa via LasIR/RhlIR circuitry. RSC Adv. 2019, 9, 40228-40239. [CrossRef]

250. Nain, Z.; Sayed, S.B.; Karim, M.M.; Islam, M.A.; Adhikari, U.K. Energy-optimized pharmacophore coupled virtual screening in the discovery of quorum sensing inhibitors of LasR protein of Pseudomonas aeruginosa. J. Biomol. Struct. Dyn. 2019, 38, 5374-5388. [CrossRef]

251. Singh, S.; Bhatia, S. In silico identification of albendazole as a quorum sensing inhibitor and its in vitro verification using CviR and LasB receptors based assay systems. BioImpacts 2018, 8, 201-209. [CrossRef] 
252. Paczkowski, J.E.; Mukherjee, S.; McCready, A.R.; Cong, J.P.; Aquino, C.J.; Kim, H.; Henke, B.R.; Smith, C.D.; Bassler, B.L. Flavonoids supress Pseudomonas aeruginosa virulence through allosteric inhibition of quorum-sensing receptors. J. Biol. Chem. 2017, 292, 4064-4076. [CrossRef]

253. Xu, Y.; Tong, X.; Sun, P.; Bi, L.; Lin, K. Virtual screening and biological evaluation of biofilm inhibitors on dual targets in quorum sensing system. Future Med. Chem. 2017, 9, 1983-1994. [CrossRef]

254. Jha, S.K.; Rashmi, S.; Shubhra, R.S.; Singh, H.R. High throughput screening of quorum sensing inhibitors based lead molecules for Pseudomonas aeruginosa associated infections. Int. J. Pharm. Clin. Res. 2014, 6, 214-220.

255. Tan, S.Y.; Chua, S.L.; Chen, Y.; Rice, S.A.; Kjelleberg, S.; Nielsen, T.E.; Yang, L.; Givskova, M. Identification of five structurally unrelated quorum-sensing inhibitors of Pseudomonas aeruginosa from a natural-derivative database. Antimicrob. Agents Chemother 2013, 57, 5629-5641. [CrossRef] [PubMed]

256. Wei, G.; Lo, C.; Walsh, C.; Hiller, L.; Marculescu, R. In silico evaluation of the impacts of quorum sensing inhibition (QSI) on strain competition and development of QSI resistance. Sci. Rep. 2016, 6, 35136. [CrossRef] [PubMed]

257. Sharma, A.; Gupta, P.; Kumar, R.; Bhardwaj, A. dPABBs: A novel in silico approach for predicting and designing anti-biofilm peptides. Sci. Rep. 2016, 6, 21839. [CrossRef] [PubMed]

258. Kim, H.S.; Lee, S.H.; Byun, Y.; Park, H.D. 6-Gingerol reduces Pseudomonas aeruginosa biofilm formation and virulence via quorum sensing inhibition. Sci. Rep. 2015, 5, 8656. [CrossRef]

259. Gopu, V.; Meena, C.K.; Shetty, P.H. Quercetin influences quorum sensing in food borne bacteria: In vitro and in silico evidence. PLOS ONE 2015, 10, e0134684. [CrossRef]

260. Xu, Z.; Fang, X.; Wood, T.K.; Huang, Z.J. A systems-level approach for investigating Pseudomonas aeruginosa biofilm formation. PLOS ONE 2013, 8, e57050.

261. Sahner, J.H.; Brengel, C.; Storz, M.P.; Groh, M.; Plaza, A.; Müller, R.; Hartmann, R.W. Combining in Silico and biophysical methods for the development of Pseudomonas aeruginosa quorum sensing inhibitors: An alternative approach for structure-based drug design. J. Med. Chem. 2013, 56, 8656-8664. [CrossRef]

262. Amin, E.A.; Welsh, W.J. A preliminary in silico lead series of 2-phthalimidinoglutaric acid analogues designed as MMP-3 inhibitors. J. Chem. Inf. Model. 2006, 46, 2104-2109. [CrossRef]

263. Ekins, S.; Mestres, J.; Testa, B. In silico pharmacology for drug discovery:applications to tagrets and beyond. Br. J. Pharmacol. 2007, 152, 21-37. [CrossRef] 